\title{
Nur7 Is a Nonsense Mutation in the Mouse Aspartoacylase Gene That Causes Spongy Degeneration of the CNS
}

\author{
Maria Traka, ${ }^{1}$ Robert L. Wollmann, ${ }^{2}$ Sonia R. Cerda, ${ }^{3}$ Jason Dugas, ${ }^{4}$ Ben A. Barres, ${ }^{4}$ and Brian Popko ${ }^{1}$ \\ ${ }^{1}$ Jack Miller Center for Peripheral Neuropathy, Department of Neurology, and Departments of ${ }^{2}$ Pathology and ${ }^{3}$ Medicine, Division of Gastroenterology, The \\ University of Chicago, Chicago, Illinois 60637, and ${ }^{4}$ Department of Neurobiology, Stanford University School of Medicine, Stanford, California 94305-5125
}

Aspartoacylase (ASPA) is an oligodendrocyte-restricted enzyme that catalyzes the hydrolysis of neuronally derived $N$-acetylaspartate (NAA) to acetate and aspartic acid. ASPA deficiency leads to the fatal childhood autosomal recessive leukodystrophy Canavan disease (CD). Here we demonstrate that the previously described ENU-induced nur7 mouse mutant is caused by a nonsense mutation, Q193X, in the Aspa gene $\left(A s p a^{n u r 7}\right)$. Homozygous Aspa $a^{\text {nur7nur7 }}$ mice do not express detectable Aspa protein and display an early-onset spongy degeneration of CNS myelin with increased NAA levels similar to that observed in CD patients. In addition, CNS regions rich in neuronal cell bodies also display vacuolization. Interestingly, distinct myelin rich areas, such as the corpus callosum, optic nerve, and spinal cord white matter appear normal in $A s p a^{\text {nur } 7 / n u r 7}$ mice. Reduced cerebroside synthesis has been demonstrated in CD patients and animal models. To determine the potential relevance of this observation in disease pathogenesis, we generated $A s p a^{n u r 7 / n u r} 7$ mice that were heterozygous for a null allele of the gene that encodes the enzyme UDP-galactose:ceramide galactosyltransferase (Cgt), which is responsible for catalyzing the synthesis of the abundant myelin galactolipids. Despite reduced amounts of cerebrosides, the $\mathrm{Aspa}^{\text {nur } 7 / n u r 7}{ } \mathrm{Cgt}^{+/-}$ mice were not more severely affected than the $A s p a^{\text {nur7 }}$ mutants, suggesting that diminished cerebroside synthesis is not a major contributing factor in disease pathogenesis. Furthermore, we found that myelin degeneration leads to significant axonal loss in the cerebellum of older Aspanur7 mutants. This finding suggests that axonal pathology caused by CNS myelin defects may underlie the neurological disabilities that CD patients develop at late stages of the disease.

Key words: ASPA; Canavan disease; $N$-acetylaspartate (NAA); spongy degeneration; vacuolation; leukodystrophy

\section{Introduction}

Canavan disease $(\mathrm{CD})$ is a rare recessive autosomal white matter leukodystrophy (Canavan, 1931; van Bogaert and Bertrand, 1949) that is caused by mutations of the aspartoacylase gene (ASPA) (Matalon et al., 1988). The disease has a high prevalence in people of Ashkenazi Jewish origin (Matalon et al., 1995), and it is characterized by the presence of widespread spongy degeneration in the brain and spinal cord (Adachi et al., 1973). Affected individuals suffer from mental retardation, weakness, blindness, and functional disability, and most die by the age of five (Matalon et al., 1995).

ASPA is highly expressed in mature oligodendrocytes (Baslow et al., 1999; Madhavarao et al., 2004; Dugas et al., 2006), where it catalyzes the hydrolysis of the most abundant amino acid in the

Received April 7, 2008; revised Sept. 19, 2008; accepted Sept. 22, 2008.

This work was supported by grants from the National Institutes of Health (NS027336) and the Canavan Research Illinois and Jacob's Cure to B.P. and the Myelin Repair Foundation to B.P. and B.A.B. Dr. Maria Traka was supported by a National Multiple Sclerosis Society postdoctoral fellowship award. We are thankful to Dr. Monica Justice for providing the ENU-induced nur7 mutant mouse line, as well as Dr. Aryan Namboodiri and Dr. James Garbern for providing Aspa antibodies. We also thank Dr. Josh Kurutz for helping with the NMR analysis, Dr. Vytas Bindokas and Kavin Arasi for their assistance with ImageJ analysis software, Darlene Staines-Douglas for her critical comments on this manuscript, Eliot Popko for his help videotaping the mice, and Erdong Liu and Hanson Ho for their skillful technical assistance.

Correspondence should be addressed to Brian Popko, Jack Miller Center for Peripheral Neuropathy, Department of Neurology, MC 2030, The University of Chicago, Chicago, IL 60637. E-mail: bpopko@uchicago.edu. DOI:10.1523/JNEUROSCI.1490-08.2008

Copyright $\odot 2008$ Society for Neuroscience $\quad$ 0270-6474/08/2811537-13\$15.00/0 brain, $N$-acetylaspartate (NAA) (Moffett et al., 2007) to acetate and aspartic acid (Kaul et al., 1991). ASPA expression is limited to the CNS, where its activity peaks at the beginning of the second postnatal week in the mouse brain, the period of active myelination (D'Adamo et al., 1973; Bhakoo et al., 2001; Kirmani et al., 2003). ASPA deficiency results in the accumulation of NAA at high levels in the brain and its abnormal excretion in the urine of CD patients (Matalon et al., 1988). Since CD was linked to ASPA gene mutations (Matalon et al., 1989), a considerable effort has been made toward understanding the mechanism of disease pathology. Despite these efforts, there is not yet a clear link between deficient NAA hydrolysis and the myelin degeneration observed in CD (Matalon et al., 1995).

Recently, low acetate levels were detected in the brains of Aspa deficient knock-out mice, which likely results in the reduced synthesis of cerebrosides (galactocerebroside and its sulfated derivate sulfatide) and other myelin lipids observed in these animals (Madhavarao et al., 2005). In the same study, reduced cerebroside levels were also detected in the white matter from a human $\mathrm{CD}$ patient. These findings provide the foundation for the hypothesis that ASPA's function is essential for proper CNS myelination because of its role in supplying NAA-derived acetate for myelin lipid synthesis (Ledeen et al., 2006; Namboodiri et al., 2006).

Here, we describe the identification of a nonsense mutation, Q193X, in the Aspa gene of the previously described (Kile et al., 
2003) ENU-induced nur7 mouse mutant $\left(A s p a^{n u r}\right)$. The Aspa $a^{\text {nur } 7}$ mutation results in the absence of detectable Aspa protein expression in $A s p a^{\text {nur7 }}$ homozygous mutant mice, which display severe spongy degeneration throughout the CNS, strikingly resembling CD. We used the Aspa $a^{\text {nur7/nur7 }}$ mice to test the hypothesis that the reduced synthesis of the cerebroside lipids, normally found abundant in myelin (Norton and Cammer, 1984), is essential for the development of disease pathology. Moreover, we performed a detailed analysis of the Aspan $a^{\text {nur7 }}$ mutant phenotype at early and late stages of the disease to gain a better understanding of the process and the progression of CNS pathology in CD.

\section{Materials and Methods}

Mice. Nur7 (Kile et al., 2003) heterozygotes on the C57BL/6J background were provided by Dr. Monica Justice (Department of Molecular and Human Genetics, Baylor College of Medicine, Houston, TX). The mice were housed under pathogen-free conditions and all animal studies were conducted in compliance with The University of Chicago's Animal Care and Use Committee (IACUC) guidelines.

Gene mapping. Nur7 heterozygote females were outcrossed to Balbc/J males to produce F1 nur7 heterozygotes, which were intercrossed to obtain F2 nur7 homozygote mice. Genomic DNA samples from 71 affected F2 mice, derived from multiple founders, were PCR genotyped for Single Sequence Length Polymorphism (SSLP) markers localized within the $24 \mathrm{cM} \operatorname{Trp} 53 /$ Wnt3 interval of chromosome 11. The sequence for each SSLP marker was amplified by using a WellRED dye (D2-PA, D3$\mathrm{PA}$, or D4-PA) 5'-end labeled sense primer (Sigma-Genosys, Proligo primers) and an unlabeled antisense primer [Integrated DNA Technologies (IDT)]. The PCR fragments were detected by the Beckman Coulters' CEQ 8000 Genetic analysis system (Beckman) and linkage analysis was performed by using the Map Manager QT software (Manly and Olson, 1999).

Antibodies. Two rabbit polyclonal antibodies that recognize Aspa were used; one that was developed against purified recombinant mouse Aspa (Madhavarao et al., 2004) was kindly provided by Dr. Aryan Namboodiri (Uniformed Services University of the Health Sciences, Bethesda, MD) and it was used for immunohistochemistry; another one that was developed against the mouse Aspa peptide SEDLPYEVRRAQEINHLFG (residues 83-101) (Hershfield et al., 2006) was generously provided by Dr. James Garbern (Wayne State University, Detroit, MI) and it was used for Western blotting. The CC-1 mouse (anti-APC, Ab-7) monoclonal antibody was purchased from Calbiochem, the rabbit polyclonal antibody against myelin-associated glycoprotein (MAG) from Invitrogen, the mouse monoclonal antibodies against anti-myelin basic protein (MBP; SMI-99P), 2',3' -cyclic nucleotide phosphodiesterase(CNP1; SMI-91R) and glial fibrillary acidic protein (Gfap, SMI-22R) from Covance, the mouse monoclonal antibodies against anti- $\beta / \mathrm{A} 4$ amyloid precursor protein (APP; 22C11 clone), and the Neuron-Specific Nuclear-Protein $(\mathrm{NeuN})$ and the rat monoclonal antibody against platelet derived growth factor receptor, $\alpha$ (Pdgfra, Clone APA5) from Millipore and the mouse monoclonal antibodies against $\alpha$-actin (clone AC-40) and calbindin (clone CB-955) from Sigma.

Histology, immunohistochemistry, and EM analysis. Mice were perfused through the heart with $4 \%$ paraformaldehyde in $0.1 \mathrm{~m}$ phosphate buffer, $\mathrm{pH} 7.3$, and the brains and spinal cords were dissected and postfixed for $2 \mathrm{~h}$ in the same fixative and cryoprotected with $30 \%$ sucrose in $1 \times \mathrm{PBS}$, $\mathrm{pH} 7.4$, for $48 \mathrm{~h}$ at $4^{\circ} \mathrm{C}$ to be sectioned in a cryostat at a $10 \mu \mathrm{m}$ thickness. For general histological evaluation the tissues were postfixed in the fixative for $1-2 \mathrm{~d}$ at $4^{\circ} \mathrm{C}$, processed by a routine paraffin protocol, then paraffin sections were cut at a $6 \mu \mathrm{m}$ thickness and stained with hematoxylin and eosin (HE). For immunohistochemistry, the cryostat sections were treated with acetone at $-20^{\circ} \mathrm{C}$ for $10 \mathrm{~min}$ and then blocked for $1 \mathrm{~h}$ with $1 \times$ PBS containing $5 \%$ normal goat serum and $0.1 \%$ Triton X-100. Incubations with the primary antibodies were performed in the blocking solution at $4^{\circ} \mathrm{C}$ overnight. The sections were washed several times with $1 \times$ PBS and then incubated with the secondary antibodies anti-mouse Alexa Fluor 594, anti-rabbit Alexa Fluor 488, and anti-rat Alexa Fluor 594 (Invitrogen) for $2 \mathrm{~h}$ at room temperature, washed with $1 \times \mathrm{PBS}$, and mounted with the Vectashield mounting medium (Vector Laboratories). Immunostaining for APP and calbindin was performed on paraffin sections after their deparaffinization and heat-induced target retrieval. After the primary antibody incubation sections were processed with the peroxidase-based Envision kit (DAKO) for antigen detection, followed by counterstaining with $\mathrm{HE}$. All sections were analyzed by a fluorescence microscope (Zeiss Axiovert-25; Carl Zeiss) and a Leica SP2-AOBS laserscanning microscope using a $40 \times$ or a $60 \times$ oil objective and a pinhole size of 1.0 airy disk units. For electron microscopy (EM) analysis the mice were deeply anesthetized first with intraperitoneal injections of Avertin (tribromoethanol, Sigma) at the dosage of $0.5 \mathrm{mg} / \mathrm{g}$, then they were perfused transcardially with $0.1 \mathrm{~m}$ Millonig's buffer containing $4 \%$ paraformaldehyde and $2.5 \%$ glutaraldehyde and postfixed in the same fixative, and the brain and spinal cord tissues were isolated and processed as previously described (Dupree et al., 1998). Semithin sections (1 $\mu \mathrm{m}$ thickness) were stained with toluidine blue and ultrathin sections (60-90 $\mathrm{nm}$ thickness) were stained with uranyl acetate-lead citrate and examined on a FEI Tecnai F30 scanning transmission electron microscope (FEI Company). To perform axonal counts in the cerebellar white matter, the cerebellum was divided into $4-6$ segments and each one was used for cutting semithin coronal sections that were stained with toluidine blue. Axonal counts were performed using the ImageJ analysis software (NIH Image software).

Western blotting. Brain tissues were harvested from postnatal day $(\mathrm{P})$ 21 and P70 Aspanur7 homozygous and heterozygous mice and homogenized in $5 \mathrm{ml}$ of buffer composed of $50 \mathrm{~mm}$ Tris- $\mathrm{HCl} \mathrm{pH} \mathrm{7.2,} \mathrm{1 \%} \mathrm{SDS,} 1$ mM PMSF, $5 \mathrm{~mm}$ EDTA, and $2 \mu \mathrm{g} / \mathrm{ml}$ aprotinin. Samples were centrifuged for $15 \mathrm{~min}$ at $10,000 \mathrm{rpm}$ at $4^{\circ} \mathrm{C}$, and the supernatants were isolated for further analysis. The protein concentration was determined by the Bradford protein assay (Bio-Rad Laboratories) and 30-100 $\mu$ g of protein extracts were run on a $12 \%$ SDS-PAGE gel and then transferred to a nitrocellulose membrane. The blots were blocked with Tris-buffered saline with Tween 20 (TBST) containing 5\% nonfat dry milk and incubated overnight with the primary antibody (anti-Aspa 1:5000, anti-MAG 1:1000, anti-MBP 1:2000, anti-CNP1 1:1000) diluted in the blocking buffer. Immunopositive bands were detected after a $2 \mathrm{~h}$ incubation with a peroxidase-conjugated antibody (anti-mouse or anti-rabbit HRP antibody at 1:5000 dilution; GE Healthcare) by using the ECL detection system (GE Healthcare). The blots were washed thoroughly in TBST and re-incubated with the anti- $\alpha$-actin mouse monoclonal antibody (1:1000 dilution) for the normalization of the protein levels in each sample.

RT-PCR analysis. Total RNA was extracted from the brains of Aspanur homozygous and heterozygous mice at P15, P21, and P70 by using the TRIazol reagent (Invitrogen). Each sample (1-5 $\mu \mathrm{g})$ was treated with DNase I (Invitrogen) and the cDNA was synthesized by the Superscript II First-Strand system for RT-PCR (Invitrogen). RT-PCR analysis on the expression of S-MAG and L-MAG mRNA isoforms was performed on P70 cDNA by using the Hotstart Master mix PCR Kit (QIAGEN) and the conditions described by Fujita et al. (1998). The constitutively expressed gene cyclophilin was used as an internal RNA control and it was amplified separately by using the sense $5^{\prime}$-atatgaaggtgctcttcgccgccg-3' and the antisense $5^{\prime}$-cattggtgtctttgcetgcattggc- $3^{\prime}$ primers. The S-MAG and L-MAG RT-PCR products were detected by gel electrophoresis on a $2.5 \%$ agarose gel containing 1.5\% Nusieve agarose (Lonza) and the optical intensity of each band was counted by the ImageJ analysis software to calculate the ratio of S-MAG and L-MAG expression. Real-time RT-PCR analysis was performed on P15, P21, and P70 brain cDNA samples by the iQ Supermix (Biorad Laboratories) on a real-time PCR detection system (model iQ; Biorad Laboratories) and by using the following oligonucleotides (IDT): mouse Aspa sense primer: CCGCCCTTGGATTGGTAATGA; mouse Aspa antisense primer: ACTGGCTAAGGAATGGCACTG; mouse Aspa probe: ACGTCCAGCCCTGCTCTGTGAACT; mouse PLP sense primer: CACTTACAACTTCGCCGTCCT; mouse PLP antisense primer: GGGAGTTTCTATGGGAGCTCAGA; mouse PLP probe: AACTCATGGGCCGAGGCACCAA; mouse MAG sense primer: CGTCTCTGTGGGGCTGACAG; mouse MAG antisense primer: AGGTAGAGGCTCTTGGCAACTG; mouse MAG probe: CGCCGCCGCTGCTGACTTGGATG; mouse MBP sense primer: GCTCCCTGCCCCAGAAGT; mouse MBP antisense primer: TGTCACAATGTTCTTGAAGAAATGG; mouse MBP 
A

SSLP Markers

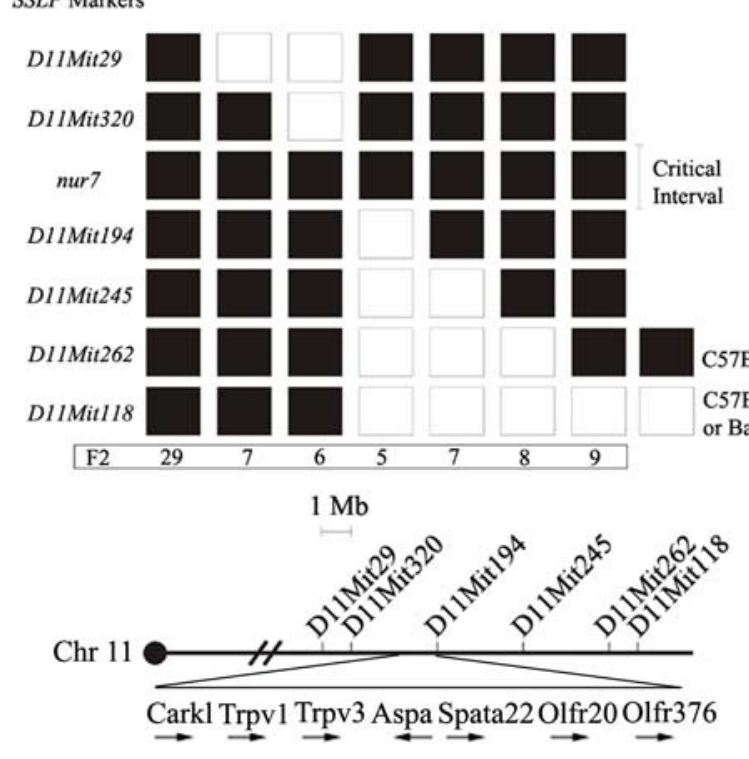

C

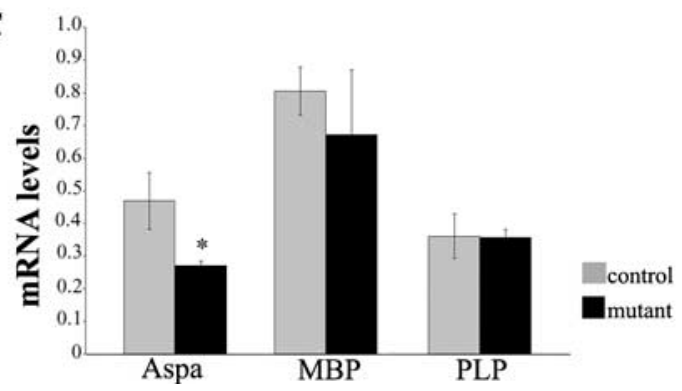

B
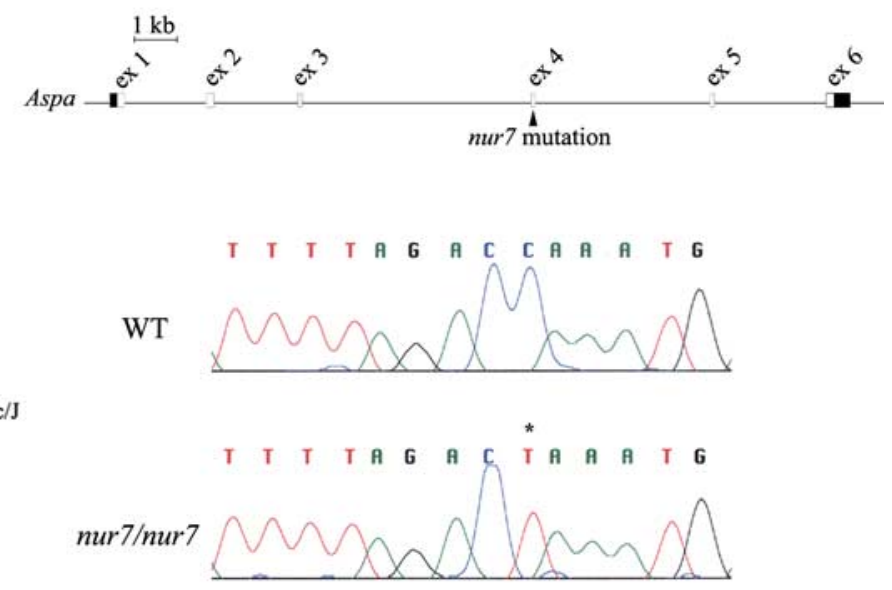

Figure 1. Nur 7 is a nonsense mutation of the Aspa gene that eliminates Aspa protein expression. A, Genotyping of 71 affected F2 progeny for SSLP markers on chromosome 11 mapped the nur7 locus between the D11Mit320 and D11Mit194 loci, which corresponds to $\sim 2.5 \mathrm{Mb}$ on the physical map and contains the candidate gene locus Aspa among other genes. The number of F2 affected mice with each genotype is shown in the bar at the bottom of the diagram, which describes recombination events between the nur 7 locus and the SSLP markers. $B$, Sequencing of the Aspa open reading frame in the wild-type (WT) and nur7//nur7 mutant mice revealed a C to T transition in the coding nucleotide 577 (denoted with a star) in the mutants, which is located at exon 4. C, An 40\% decrease of Aspa mRNA levels ( ${ }^{*} p<0.05$ ) was detected in the brain of P15 Aspa $a^{\text {nur7 }}$ homozygous (mutant, $n=3$ ) mice, which showed normal MBP and PLP mRNA levels ( $p>0.05$ ) compared with heterozygous (control, $n=3$ ) mice. Error bars indicate SD of the mean. D, Double immunostaining for Aspa (green) and the mature oligodendrocyte marker CC 1 (red) on brain sections of P21 Aspa $a^{\text {nur7 }}$ heterozygous ( + / - ) mice showed that Aspa was expressed by many CC-1-positive oligodendrocytes (yellow), whereas in Aspa $a^{\text {nur7 }}$ mutants (-/ - ) of the same age, no Aspa expression could be detected in (C-1-positive cells. $\boldsymbol{E}$, Western blot analysis of total protein brain extracts demonstrated the presence of a $\sim 37 \mathrm{kDa}$ band in Aspan ${ }^{\text {nur }}$ heterozygous ( $+/-$ ) mice and its absence in Aspan ${ }^{\text {nur }}$ mutants (-/-) at P21, which also lacked expression of the $\sim 21.7 \mathrm{kDa}$ truncated mutant protein (MT). Actin expression was used for normalization of the protein levels in each sample. Scale bar, $20 \mu \mathrm{m}$.

probe: AGCACGGCCGGACCCAAGATG; mouse GAPDH sense primer: CTCAACTACATGGTCTACATGTTCCA; mouse GAPDH antisense primer: CCATTCTCGGCCTTGACTGT; mouse GAPDH probe: TGACTCCACTCACGGCAAATTCAACG.

Sequence analysis. The reverse-transcribed cDNA from P21 nur7 homozygotes and age-matched wild-type mice was used for the PCR amplification of four overlapping products that cover the complete mouse Aspa open reading frame. In addition, genomic DNA from these mice was used for amplifying exon 4 of the mouse Aspa gene with the sense $5^{\prime}$-tgtaaaagtgattgtgtctcctgt- $3^{\prime}$ and antisense $5^{\prime}$-acaactgccacccaccac- $3^{\prime}$ primers. Each PCR product was purified by the QIAquick PCR Purification Kit (QIAGEN) and sequenced in both directions with PCR primers.

Myelin lipid analysis. Myelin was isolated from the brain of P21 wildtype, Aspa $a^{\text {nur } 7 / n u r 7}$, and $A s p a^{\text {nur } 7 / n u r 7} ; C g t^{+/-}$mice by using the sucrose gradient method (Norton and Poduslo, 1973). Briefly, each brain tissue was homogenized in $0.32 \mathrm{M}$ of sucrose and layered on $0.85 \mathrm{M}$ sucrose and then centrifuged at $70,000 \times g$ at $4^{\circ} \mathrm{C}$ for $30 \mathrm{~min}$. The interface (crude myelin fraction) was subjected to hypoosmotic shock and myelin was collected as a pellet by centrifugation $\left(12,000 \times g\right.$, at $4^{\circ} \mathrm{C}$ for $\left.10 \mathrm{~min}\right)$ and then purified again by sucrose gradient ultracentrifugation followed by three additional rounds of hypoosmotic shock and centrifugation. The final myelin pellet was dissolved in $0.5 \mathrm{ml}$ of $50 \mathrm{~mm}$ Tris- $\mathrm{HCl}, \mathrm{pH} 7.2$, and the protein levels were counted by using the Bio-Rad Bradford Assay. Lipids were extracted from each myelin suspension by mixing the sample with $6 \mathrm{ml}$ of 1:1 chloroform/methanol solution according to a modified protocol (Benjamins et al., 1976) of the method of Folch et al. (1957). The myelin lipid samples at $40 \mu \mathrm{g}$ were analyzed by thin-layer chromatography (TLC) on a silica gel plate (HLF, $250 \mu \mathrm{m}$; Analtech) in the solvent system of chloroform-methanol-water (70:30:4). The lipid bands were visualized by spraying the plates with $0.05 \%$ primulin solution in acetone:water $(8: 2 \mathrm{v} / \mathrm{v})$ and UV scanning with a Storm 840 Fluorescence Imaging system (Molecular Dynamics). Quantification of lipids was done by densitometry with the ImageJ analysis software.

Rotarod treadmill test. The rotarod treadmill (Columbus Instruments) test was used for the analysis of the motor performance of P42-P56 Aspa $a^{\text {nur7/nur7 }}(n=7)$, Aspa $a^{\text {nur7/nur7 }} ; \mathrm{Cgt}^{+/-}(n=7)$, and wild-type C57BL/6J female mice $(n=10)$. The mice were tested for the time (latency) they maintained themselves on the rod rotating at the accelerating speed mode (5-65 rpm) during a 5 min trial session. The latency time was monitored for each mouse by performing 3 sessions per day for 3 consecutive days.

${ }^{1} \mathrm{H}$-NMR analysis. Aqueous metabolites were extracted from the 

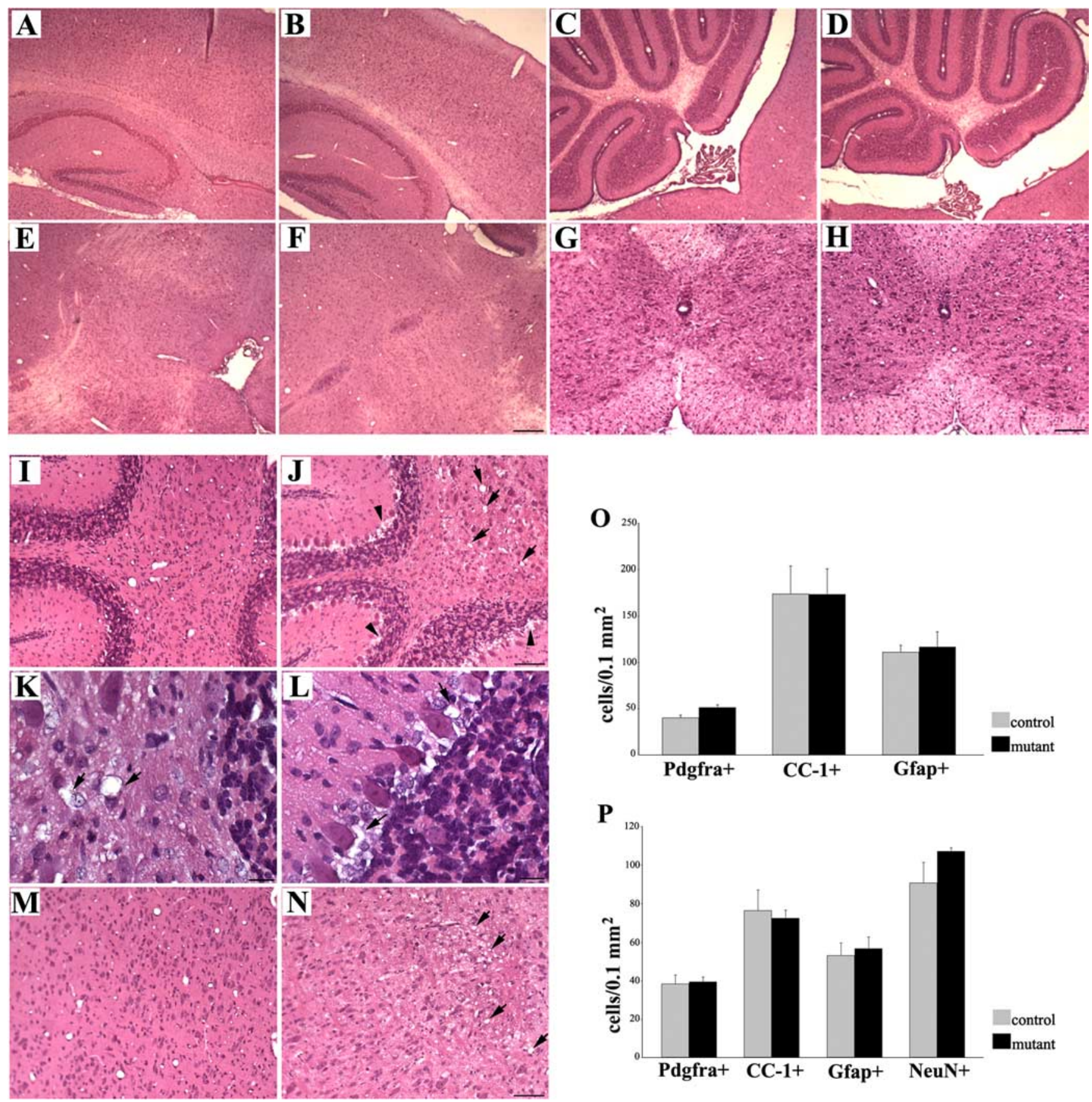

Figure 2. The Aspar $a^{\text {nur7 }}$ mutants start showing limited brain defects around P14. HE staining on sagittal paraffin brain and spinal cord sections of $A s p a^{\text {nur7 }}$ mutants at P10 and P14 are shown. At P10, the forebrain $(\boldsymbol{B})$, cerebellum $(\boldsymbol{D})$, the brainstem (pons, $\boldsymbol{F})$, and the spinal cord $(\boldsymbol{H})$ showed no defects in the Aspan ${ }^{\text {ur7 }}$ mutants compared with their normal heterozygous littermates $(\boldsymbol{A}, \boldsymbol{C}, \boldsymbol{E}, \boldsymbol{G})$. At P14, vacuoles were present in the cerebellar white matter (arrows in $\boldsymbol{J}$ and at higher magnification in $\boldsymbol{K}$ ), the Purkinje cell layer (arrowheads in $\boldsymbol{J}$ and arrows at higher magnification in $\boldsymbol{L}$ ), and the pons ( $\boldsymbol{N}$, arrows) of the Aspa ${ }^{\text {nur7 }}$ mutants. In $\boldsymbol{I}$ and $\boldsymbol{M}$, corresponding control regions from Aspa ${ }^{\text {nur7 }}$ heterozygous littermates are shown. $\mathbf{O}, \boldsymbol{P}$, Counts of Pdgfra, C(-1, Gfap-positive cells in the P14 cerebellar white matter $(\mathbf{O})$ and the medial pons $(\boldsymbol{P})$ in which NeuN-positive cells were also included; no differences between $A$ spa ${ }^{\text {nur }}$ homozygous (mutant) and heterozygous (control) mice were $\operatorname{detected}(p>0.05, n=3)$. Error bars indicate SD of the mean. Scale bars: $200 \mu \mathrm{m}(\boldsymbol{A}-\boldsymbol{F}), 100 \mu \mathrm{m}(\boldsymbol{G}-\boldsymbol{J}$ and $\boldsymbol{M}, \boldsymbol{N}), 20 \mu \mathrm{m}(\boldsymbol{K}, \boldsymbol{L})$.

brainstem, the cerebellum, the cerebral cortex and the spinal cord of P21 Aspa $a^{\text {nur }}$ homozygotes and heterozygotes by the using the perchloric acid (PCA, Sigma) method described by Le Belle et al. (2002). Briefly, the tissues were rapidly frozen after dissection and ground with a mortar and pestle under liquid nitrogen. The ground tissue was mixed afterward with cold $12 \%$ PCA and the mixture was centrifuged at 13,000 rpm for $20 \mathrm{~min}$. The PCA supernatants were neutralized with $1 \mathrm{~m} \mathrm{NaOH}$ and then submitted for the NMR analysis as $330 \mu \mathrm{l}$ aliquots, to which it was added DSS-d6 (a chemical shift reference, $1.0 \mathrm{~mm}$ final concentration, Cambridge Isotope Laboratories). Solvent was exchanged for $\mathrm{D}_{2} \mathrm{O}$ with three rounds of freeze-drying/dissolution of the desiccated samples in $\mathrm{D}_{2} \mathrm{O}$ (99.96\% D, low paramagnetic, Cambridge Isotope Laboratories). Samples in $\mathrm{D}_{2} \mathrm{O}$ were transferred in $330 \mu$ laliquots to high-grade reducedvolume NMR tubes (Shigemi). NMR data were acquired at $25^{\circ} \mathrm{C}$ on a 600 $\mathrm{MHz}$ Varian Inova spectrometer equipped with a cryogenic probe; each spectrum used 128 transients, using $90^{\circ}$ pulses, $2 \mathrm{~s}$ of acquisition, and $20 \mathrm{~s}$ interscan delays. Data were analyzed with the program VNMR. Relative metabolite concentrations were reckoned by measuring peak intensities relative to that for creatine at $3.0 \mathrm{ppm}$.

Statistical analysis. Data from age-matched control (wild-type or 

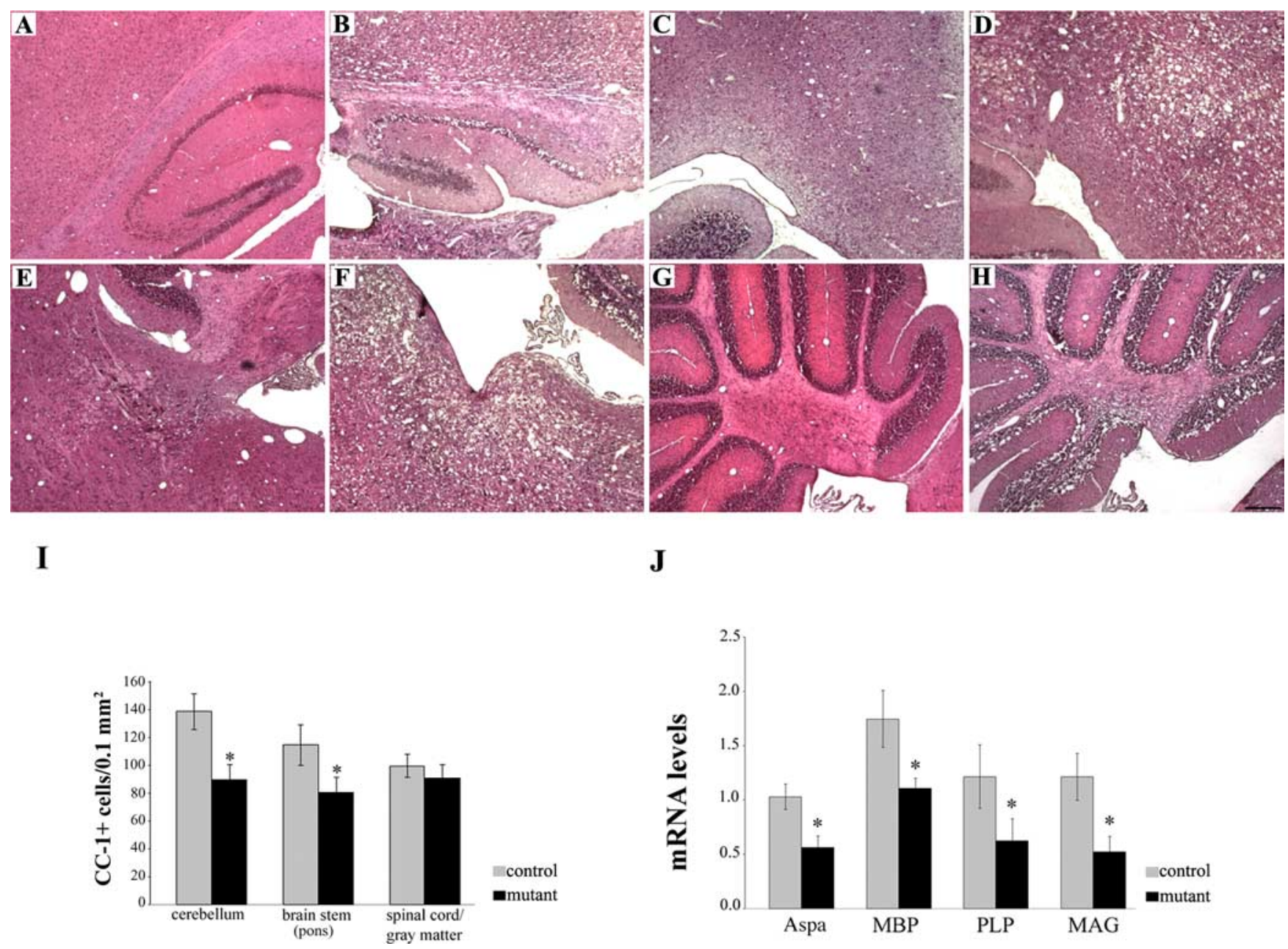

Figure 3. Extensive spongy degeneration with oligodendrocyte loss develops in the brain of Aspa $a^{\text {nur7 }}$ mutants at P21. HE staining on sagittal paraffin sections of P21 Aspa $a^{\text {nur7 }}$ mutant brains showed vacuoles in the cerebral cortex $(\boldsymbol{B})$, the hippocampus $(\boldsymbol{B})$, the midbrain $(\boldsymbol{D})$, and pons $(\boldsymbol{F})$ as well as in the cerebellum $(\boldsymbol{H})$, where the Purkinje cell layer, the granule cell layer, and the white matter were affected. $\boldsymbol{I}$, At this age, significantly fewer oligodendrocytes were counted in the cerebellum and the brainstem (medial pons) of Aspan ${ }^{\text {nur }}$ mutant mice $\left({ }^{*} p<0.05, n=4\right.$ ), whereas they were normal in the undamaged spinal cord gray matter. J, Reduced Aspa, MBP, PLP, and MAG mRNA levels were found in the brain of Aspa $a^{\text {nur7 }}$ homozygous (mutant) mice compared with heterozygous (control) ones by real-time RT-PCR analysis ( ${ }^{*} p<0.05, n=4$ ). Error bars indicate SD of the mean. The $\boldsymbol{B}, \boldsymbol{D}, \boldsymbol{F}$, and $\boldsymbol{H}$ corresponding control regions are shown in $\boldsymbol{A}, \boldsymbol{C}, \boldsymbol{E}$, and $\boldsymbol{G}$. Scale bar, $200 \mu \mathrm{m}(\boldsymbol{A}-\boldsymbol{H})$.

$A s p a^{\text {nur7/+ }}$ ) and mutant mice (Aspa $a^{\text {nur7/nur7 }}$ or Aspa $a^{\text {nur7/nur }} ; \mathrm{Cgt}^{+/-}$) were compared by using the unpaired Student's $t$ test and the differences were considered as statistically significant at $p<0.05$.

\section{Results}

$N u r 7$ is a novel nonsense mutation of the aspartoacylase gene in the mouse

The ENU-induced nur7 mutation was originally mapped to a 24 cM region on mouse chromosome 11 between the Trp53 and Wnt3 genes by Kile et al. (2003), who used the inversion chromosome $11 \mathrm{Inv}(11) 8 \mathrm{Brd}^{\text {Trp53-Wnt3 }}$ balancer approach to isolate mutations in this region. This ENU mutagenesis screen revealed nur7 among nine other neurological mutations that mapped to chromosome 11 (Kile et al., 2003). The neurological phenotype of nur7 homozygotes was described as hypoactive in young postnatal mice and trembling during movement in adulthood. We performed a more detailed phenotypic characterization of nur7 homozygotes and found that the mutants were easily distinguished at P21 by their small body size and a wide-based ataxic gait (supplemental Video 1, available at www.jneurosci.org as supplemental material). Although the mice were able to survive beyond 12 months, they developed a more severe phenotype as they aged displaying tremors and seizures, symptoms suggestive of a myelin defect. By following a genetic linkage analysis approach that involved the genotyping of 71 affected $\mathrm{F} 2$ progeny for single sequence length polymorphic markers (SSLPs) confined within the Trp53/Wnt3 region of chromosome 11 (supplemental Table 1, available at www.jneurosci.org as supplemental material), we were able to localize the nur7 mutation to cytoband 11B4, between the D11Mit320 and D11Mit194 markers (Fig. 1A), which corresponds to $\sim 2.5 \mathrm{Mb}$ on the physical map. According to the most recent mouse genome build 37.1 (http://www.ncbi. nlm.nih.gov/genome/guide/mouse/), there are a total of 54 genes located in the nur7 critical region. Among these genes is Aspa, which is expressed by mature oligodendrocytes in vivo (Baslow et al., 1999; Madhavarao et al., 2004) and in vitro (Dugas et al., 2006). Also, Aspa is the only gene in the critical region that is strongly upregulated during oligodendrocyte differentiation (Dugas et al., 2006). We sequenced the Aspa open reading frame in nur7 homozygotes and found a $\mathrm{C}$ to $\mathrm{T}$ transition in the coding nucleotide 577 in exon 4 (Fig. $1 B$ ), which generates a TAA stop/ nonsense codon and results in the early termination of the protein at D192. Consequently the Q193X Aspa mutation was 


\section{Brain stem}

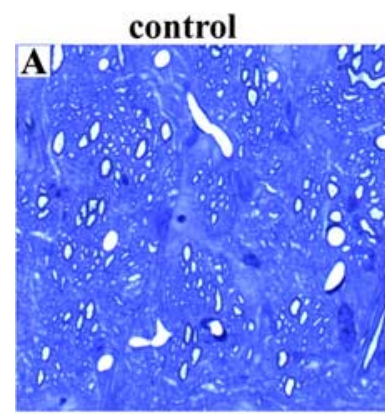

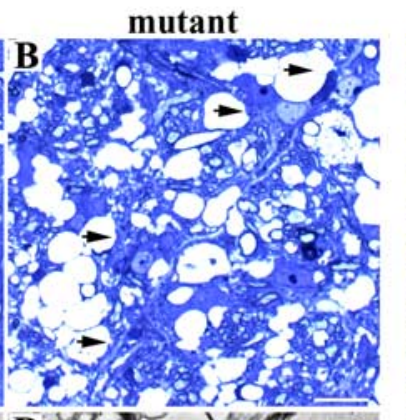
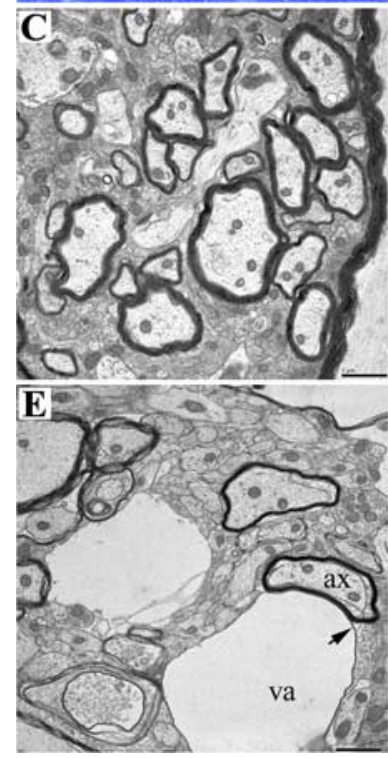
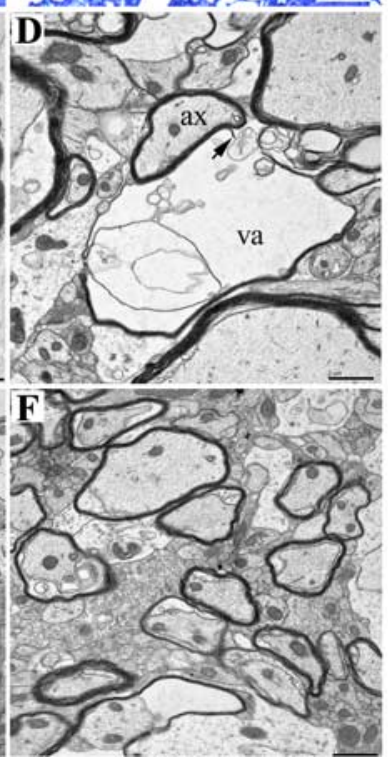

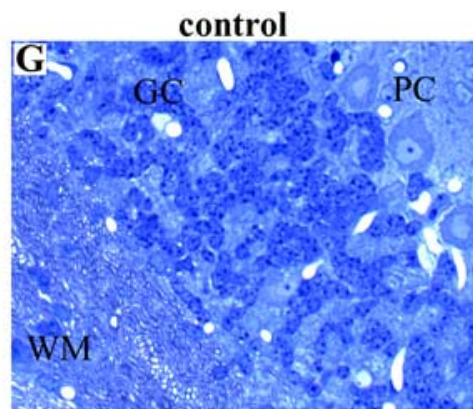

Cerebellum
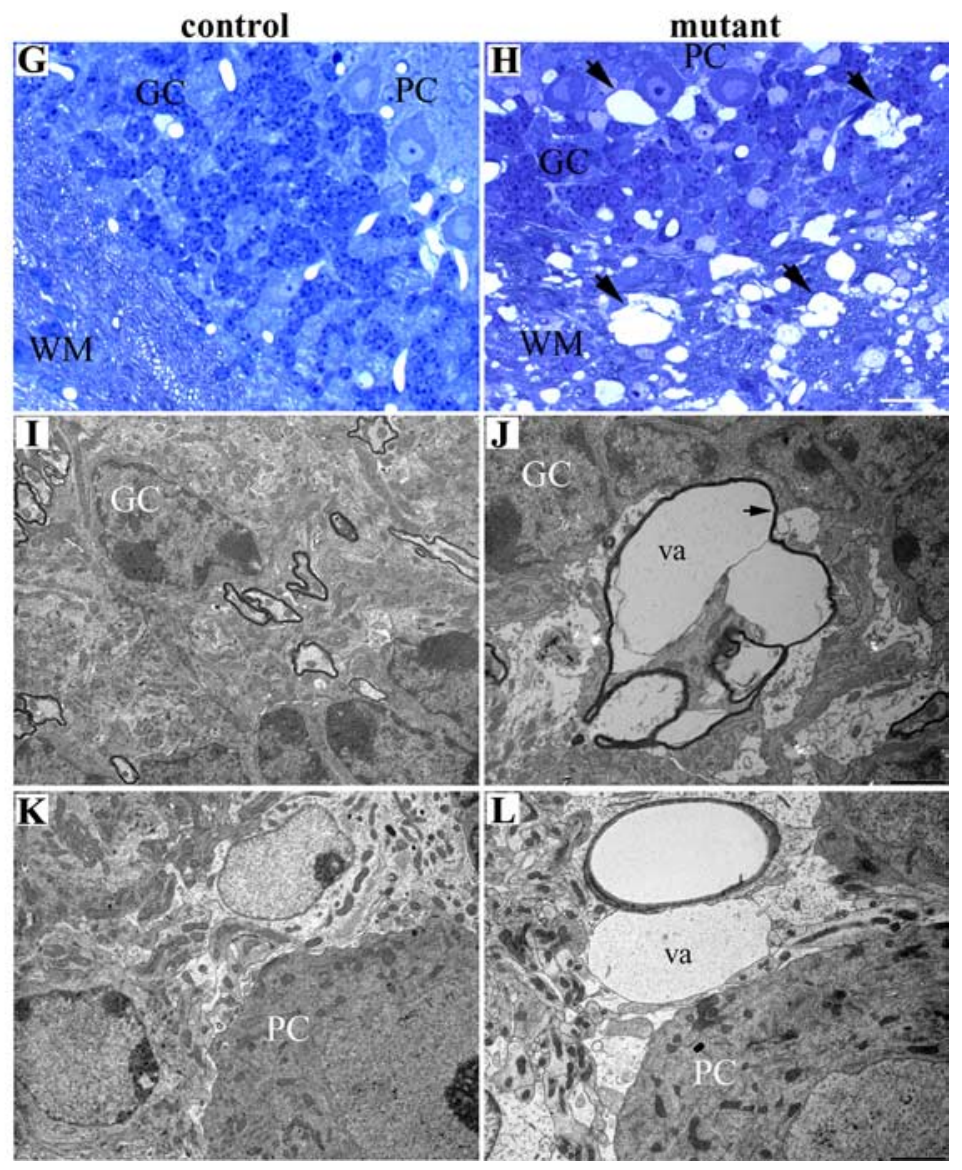

Figure 4. Vacuolation is caused by the splitting of the myelin sheath in $A s p a^{\text {nur7 }}$ mutants. $A, B, A t P 21$, the $A s p a^{\text {nur7 }}$ mutants showed many irregularly shaped vacuoles in the brainstem area ( $\boldsymbol{B}$, arrows) on toluidine blue-stained semithin sections, whereas no defects were found in the control (Aspa ${ }^{\text {nur7/++}}$ ) mice ( $\left.\boldsymbol{A}\right)$. Under EM, vacuoles ( $\boldsymbol{D}$ and $\boldsymbol{E}$, va) were seen within myelin (arrows), and they were always surrounding axons of normal appearance (ax). Additionally, the myelin sheath was much thinner in $A s p a^{\text {nur7 }}$ mutants $(\boldsymbol{F})$ compared with controls $(\boldsymbol{C})$. On toluidine blue-stained semithin sections of the mutant cerebellum, vacuoles ( $\boldsymbol{H}$, arrows) were found in the white matter (WM), the granule cell (GC) and the Purkinje cell (PC) layers. Vacuoles (va) in the layer of granule cell neurons $(J, G C)$ were also detected within myelin (arrow) on EM, whereas vacuoles in the layer of Purkinje cell neurons $(L, P C)$ appear to be formed by degenerating cell processes whose origin could not be determined. $\boldsymbol{G}, \boldsymbol{I}$, and $\boldsymbol{K}$ are the corresponding control regions of $\boldsymbol{H}, \boldsymbol{J}$, and $\boldsymbol{L}$. Scale bars: $20 \mu \mathrm{m}(\boldsymbol{A}, \boldsymbol{B}, \boldsymbol{G}$, and $\boldsymbol{H}), 1 \mu \mathrm{m}(\mathbf{C}-\boldsymbol{F}), 2 \mu \mathrm{m}(\boldsymbol{I}-\boldsymbol{L})$.

named $A s p a^{\text {nur7 }}$. Because $A s p a^{\text {nur7 }}$ is a nonsense mutation, we checked whether it might affect Aspa's expression at the mRNA level by nonsense-mediated mRNA decay, or at the protein level because of the predicted 120 amino-acid truncation in the translated mutant protein. We found that Aspa mRNA was detectable in the brain of $A s p a^{\text {nur } 7 / n u r 7}$ mice, albeit at $\sim 40 \%$ reduced levels, compared with normal $A s p a^{n u r 7}$ heterozygous mice at P15, a time point that precedes the initiation of phenotype and corresponds with normal expression of the myelin-specific genes MBP and PLP in the mutants (Fig. 1C). In contrast, no Aspa protein could be detected in oligodendrocytes (Fig. 1D) and brain extracts (Fig. $1 E)$ of the mutant animals, which also lacked expression of the predicted $21.7 \mathrm{kDa}$ truncated mutant protein.

\section{$A s p a^{\text {nur7 }}$ mutants develop an early onset CD-related pathology}

Histological analysis of HE-stained brain and spinal cord sections of Aspan $a^{\text {nur }}$ mutants at P10, the earliest time point studied, showed no defects in any CNS area examined; the forebrain, cerebellum, brainstem, and spinal cord had a normal appearance (Fig. 2). At P14, however, when Aspa shows highest activity levels in the brain (Bhakoo et al., 2006), vacuoles were detected in the cerebellar white matter (Fig. 2 J, K), in the Purkinje cell layer (Fig.
$2 J, L)$ and the brainstem (pons) (Fig. $2 N$ ) in the $A s p a^{n u r 7}$ mutants. We performed immunohistochemistry for specific cell markers to check whether the loss of Aspa expression in oligodendrocytes affects distinct cell populations in the mutant brain at this age. Oligodendrocyte precursors were stained for Pdgfra, mature oligodendrocytes for CC-1, and astrocytes for Gfap. Counts of these cells in the cerebellum white matter (Fig. 2O) and the brainstem (medial pons) (Fig. $2 P$ ), which was also checked for neuronal numbers by NeuN staining, showed no significant differences in the Aspa $a^{\text {nur }}$ mutants compared with their normal littermates. In addition, we used HE-stained brain sections to perform counts of Purkinje and granule cell neurons in cerebellar lobule I. Purkinje cell numbers were not significantly different $(p>0.05)$ in the mutant $(0.22 \pm 0.04$ cells $/ 0.01 \mathrm{~mm}$ line length, $n=3$ mice $)$ compared with control mice $(0.28 \pm 0.04$ cells $/ 0.01$ mm line length, $n=3$ mice). Furthermore, staining for calbindin, a marker for Purkinje cells, was normal in the cerebellum of P14 mutants (supplemental Fig. $1 B$, available at www.jneurosci.org as supplemental material). Granule cell numbers were found to be slightly increased $(p<0.05)$ in the mutants $(172 \pm 6$ cells/0.01 $\mathrm{mm}^{2}, n=3$ mice) compared with controls (149 \pm 2 cells/0.01 $\mathrm{mm}^{2}, n=3$ mice).

Vacuolar degeneration appears to be much more progressed 


\section{Cerebral cortex}

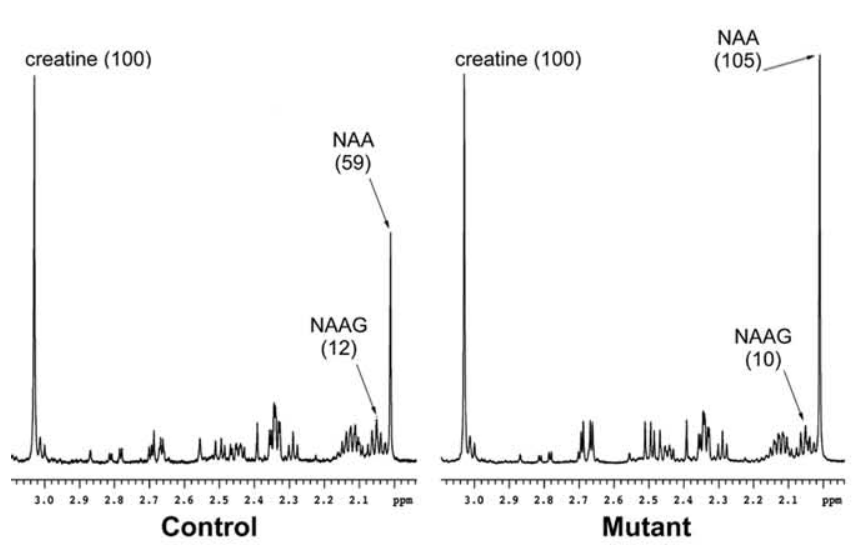

\section{Cerebellum}

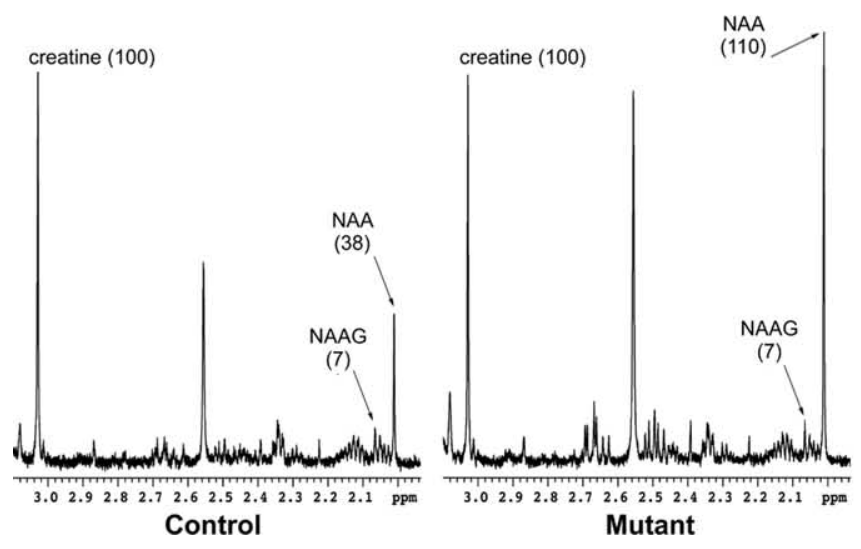

\section{Brain stem}

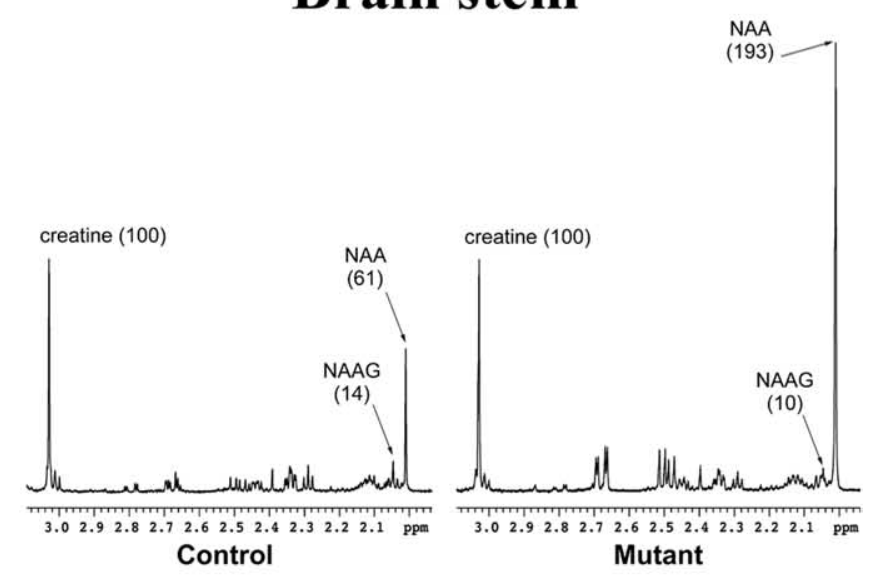

Figure 5. Aspa deficiency causes an early onset increase of NAA levels in the CNS of Aspa $a^{\text {nur7/nur7 }}$ mice. ${ }^{1} \mathrm{H}-\mathrm{NMR}$ spectra of cerebral cortex, brainstem, cerebellum, and spinal cord PCA extracts from Aspa ${ }^{\text {nur7 }}$ heterozygous (control) and homozygous (mutant) mice at P21. The intensities of the NAA and NAAG peaks were normalized in reference to that of creatine for each region to estimate the relative metabolite concentrations in each sample. NAA, but not NAAG, levels are higher in all mutant areas compared with control ones.

in Aspanur7 mutants at P21, when numerous vacuoles were detected throughout different brain areas (Fig. 3). In the forebrain, cerebral cortex (Fig. 3B), hippocampus (Fig. 3B), and subcortical white matter regions (data not shown) were affected. Vacuoles were also found in the midbrain (Fig. 3D) and the pons (Fig. $3 F$ ), as well as in the cerebellum (Fig. $3 H$ ), where the granule cell layer, the Purkinje cell layer and the white matter showed defects. It is noteworthy to mention that cerebellar white matter lesions were increasingly severe in more lateral sections of the cerebellar sagittal plane shown in Fig. $3 H$. Increased astrogliosis, a typical hallmark of CNS tissue damage, was also detected in the above mentioned areas by Gfap immunostaining (data not shown). As opposed to the brain, the spinal cord was nearly normal at this age, although it also became affected by P30 (data not shown).

At P21, the widespread formation of vacuoles coincided with oligodendrocyte loss in Aspan $a^{\text {nur/nur7 }}$ mice, which showed significantly reduced cell numbers in the lesion areas of the cerebellum and the brainstem (medial pons) (Fig. 3I), whereas no reduction in oligodendrocyte numbers was observed in the spinal cord gray matter, which was nearly intact at this age (Fig. 3I). The spinal cord gray matter showed oligodendrocyte loss at the onset of vacuolation at P30 (data not shown). The reduction of oligodendrocyte numbers in the lesion sites indicates that vacuolation might be related to myelin defects, which also occur in CD (Ada- chi et al., 1973). At P21, in addition to Aspa, the myelin-specific genes MBP, PLP, and MAG showed lower mRNA expression levels in $A s p a^{\text {nur7 }}$ mutants, consistent with oligodendrocyte loss (Fig. 3J).

The detection of vacuoles in the neuronal-rich Purkinje and granule cell layers of the mutant cerebellum prompted us to examine whether these lesions originate from neuronal cell loss. Nevertheless, counts of Purkinje and granule cells performed on HE-stained cerebellar lobule I sections showed that neither cell population was reduced $(p>0.05)$ in the mutants $(0.26 \pm 0.04$ Purkinje cells $/ 0.01 \mathrm{~mm}$ line length and $232 \pm 39$ granule cells/ $0.01 \mathrm{~mm}^{2}, n=3$ mice) compared with control mice $(0.24 \pm$ 0.003 Purkinje cells $/ 0.01 \mathrm{~mm}$ line length and $210 \pm 17$ granule cells $/ 0.01 \mathrm{~mm}^{2}, n=3$ mice). In addition, calbindin-stained Purkinje cells had a normal morphology in the mutants (supplemental Fig. $1 D$, available at www.jneurosci.org as supplemental material).

Further histological analysis of the early disease stage at P21 confirmed that myelin sheath destruction underlies the formation of vacuoles in many CNS areas of the $A s p a^{\text {nur }}$ mutants. Numerous irregularly shaped vacuoles were seen on toluidine blue-stained semithin sections of the brainstem (Fig. 4B), and they appeared on EM to be within the myelin sheath surrounding normal appearing axons (Fig. $4 D, E$ ). In addition to vacuolation, 
this area displayed evidence of hypomyelination or remyelination, because many myelinated fibers showed a reduced myelin sheath thickness (Fig. $4 F$ ) compared with fibers from control mice (Fig. 4C). Toluidine blue-stained semithin sections demonstrated that vacuoles in the mutant cerebellum are present in the white matter as well as in the neuronal-rich layers of Purkinje and granule cell neurons at P21 (Fig. $4 H$ ). EM analysis showed that vacuole formation is associated with myelin sheath splitting in the white matter area (data not shown) and in the layer of granule cell neurons (Fig. $4 J$ ). In the granule cell layer, however, vacuoles were also found that were not associated with degenerating myelin (data not shown). Moreover, EM analysis revealed that the vacuoles in the Purkinje cell layer were composed of swollen degenerating cell processes of undetermined origin (Fig. $4 L$ ). Vacuoles were conspicuously absent in myelin rich areas of the corpus callosum, the optic nerve and the spinal cord white matter, where axons with normal myelin sheath thickness were detected (data not shown).

ASPA's deficiency in CD leads to increased NAA levels in the brain (Blüml, 1999). To examine whether the loss of Aspa protein expression might have a similar effect on NAA levels in the brain of Aspa ${ }^{\text {nur } 7 / \text { nur } 7}$ mutants, ${ }^{1} \mathrm{H}$-NMR analysis was performed on tissue extracts from different CNS regions of these mice at P21. These results (Fig. 5) showed higher NAA levels in the cerebral cortex, brainstem, cerebellum, and spinal cord, whereas the levels of the NAA glutamate derivative NAAG (Neale et al., 2000) were close to control values. Nevertheless, NAAG levels might actually be higher in $A s p a^{\text {nur7 }}$ mutants compared with controls because NAAG contributes $15-20 \%$ to the acetate signal in the ${ }^{1} \mathrm{H}-\mathrm{NMR}$ spectra of the brain that is usually associated with NAA (Pouwels and Frahm, 1997; Moffett et al., 2007)

\section{The role of cerebrosides in spongy degeneration of Aspa $^{\text {nur7 }}$ mutants}

One possibility for Aspa's role in the myelination process is based on the assumption that this enzyme supplies acetate for the synthesis of myelin sheath fatty acids (D'Adamo and Yatsu 1966; Burri et al., 1991). This was supported by the finding that neuronal NAA is transferred transaxonally to oligodendrocytes, where it supplies acetyl groups for the synthesis of the myelin cerebrosides and phospholipids (Chakraborty et al., 2001).

Also, it has been recently reported that cerebrosides were significantly reduced in the white matter of a human CD patient and in the brains of Aspa knock-out mice, which also showed decreased synthesis of other myelin lipids as well as reduced acetate levels during the peak period of myelination (Madhavarao et al., 2005). Thus, one hypothesis for CD pathogenesis favors a reduced myelin lipid synthesis mechanism (Ledeen et al., 2006; Namboodiri et al., 2006), which raises the possibility that ASPA deficiency leads to spongy degeneration in the CNS of CD patients by a process that involves the reduced synthesis of cerebrosides, normally abundant in myelin. A potential role of cerebrosides in CD pathogenesis is further supported by the pathological
B
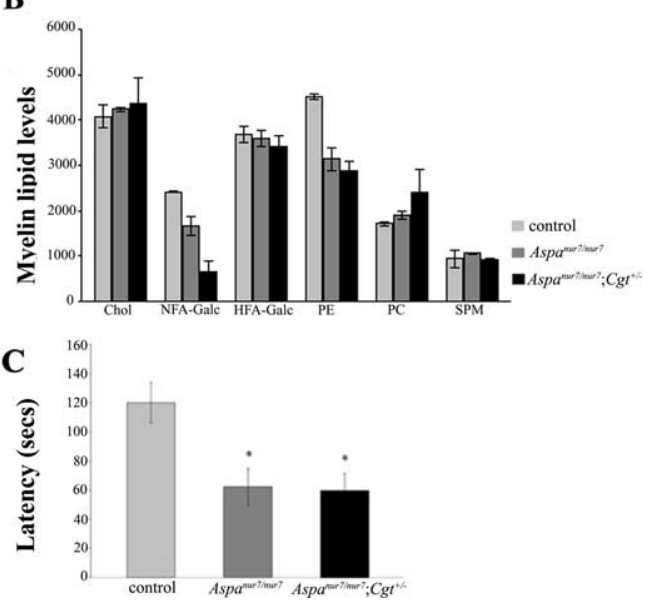

Figure 6. Lipid analysis and rotarod testing of $A s p a^{\text {nur7/nur7 }}$ and Aspa ${ }^{\text {nur7/nur7 }} ; \mathrm{Cgt}^{+/-}$mice. $A$, TLC analysis was performed in P21 wild-type (control), Aspanur7/nur7 and $A s p a^{\text {nur7/nur7 }} ; \mathrm{Cgt}^{+/-}$mice by using myelin lipid extracts isolated from two brain samples per genotype. The normal fatty acid-containing galactocerebroside (NFA-Galc) and the phosphatidyl ethanolamine (PE) Aspa $^{\text {nur7/nur7 }}$ mice and a $70 \%$ decrease in Aspa ${ }^{\text {nur7/nur7 }} ; \mathrm{Cgt}^{+/-}$ones compared with controls. C, The motor performance of mean. Chol, Cholesterol; NFA-Galc, normal fatty acid-containing galactocerebroside; HFA-Galc, hydroxy fatty acid-containing

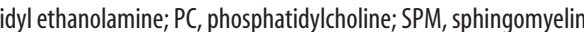

similarities between $A s p a^{\text {nur7 }}$ mutants and mice deficient for the UDP-galactose:ceramide galactosyltransferase enzyme (Ugt8a or Cgt), which are not able to synthesize the abundant myelin glycolipids galactocerebroside (Galc) and its sulfated derivative sulfatide (Coetzee et al., 1996). Cgt-null mice (Ugt8a ${ }^{\text {tm1Pop } / ~}$ Ugt8 $\mathrm{a}^{\text {tm1Pop }}$ or $\left.\mathrm{Cgt}^{-/-}\right)$show an early-onset ataxic gait and tremor, and with age they develop a progressive hindlimb paralysis and extensive myelin vacuolation throughout the CNS (Coetzee et al., 1996).

To test whether cerebroside deficiency contributes to CD pathogenesis, Aspanur7/nur7 mice were generated that are heterozygous for the null $C g t$ allele $\left(A s p a^{\text {nur } 7 / n u r 7} ; C g t^{+/-}\right)$. TLC analysis performed on myelin lipid extracts from the brains of two Aspa $a^{\text {nur7/nur7 }}$, two Aspa $a^{\text {nur7/nur7 }} ; \mathrm{Cgt}^{+/-}$and two wild-type (control) mice at P21 revealed a $40 \%$ decrease of the phosphatidyl ethanolamine (PE) in Aspa $a^{\text {nur7/nur7 }}$ and $A s p a^{\text {nur7/nur7 }} ; \mathrm{Cgt}^{+/-}$mice compared with controls (Fig. 6A,B). The normal fatty acid (NFA)-containing Galc cerebroside was also reduced in both mutants compared with controls; a $40 \%$ decrease occurred in Aspa $a^{\text {nur } 7 / n u r 7}$ mice as opposed to the $70 \%$ decrease found in Aspa ${ }^{\text {nur7/nur } 7} ; \mathrm{Cgt}^{+/-}$animals (Fig. 6A,B). The hydroxy fatty acid (HFA)-containing Galc cerebroside, however, was normal in both mutants, indicating that in contrast to NFA-containing Galc cerebroside, Aspa is not critical for its synthesis. Next, we checked whether the phenotype of the Aspa $a^{\text {nur } / n u r 7} ; \mathrm{Cgt}^{+/-}$mice is exacerbated compared with Aspanur7/nur7 mice to assess the importance of reduced cerebroside levels in CD pathogenesis. Both mutants displayed similar neuropathology (data not shown) and showed no major differences in oligodendrocyte numbers (data not shown) at the age of P21. Furthermore, the motor performance of $A s p a^{\text {nur7/nur7 }}$ and Aspa $a^{\text {nur7/nur7 }} ; \mathrm{Cgt}^{+/-}$mice was examined by testing P42-P56 mice on the accelerating rotarod treadmill, which measures motor coordination and balance. Both genotypes showed a similar decrease $(\sim 50 \%)$ of the time (latency) they spent on the rotarod compared with age-matched 

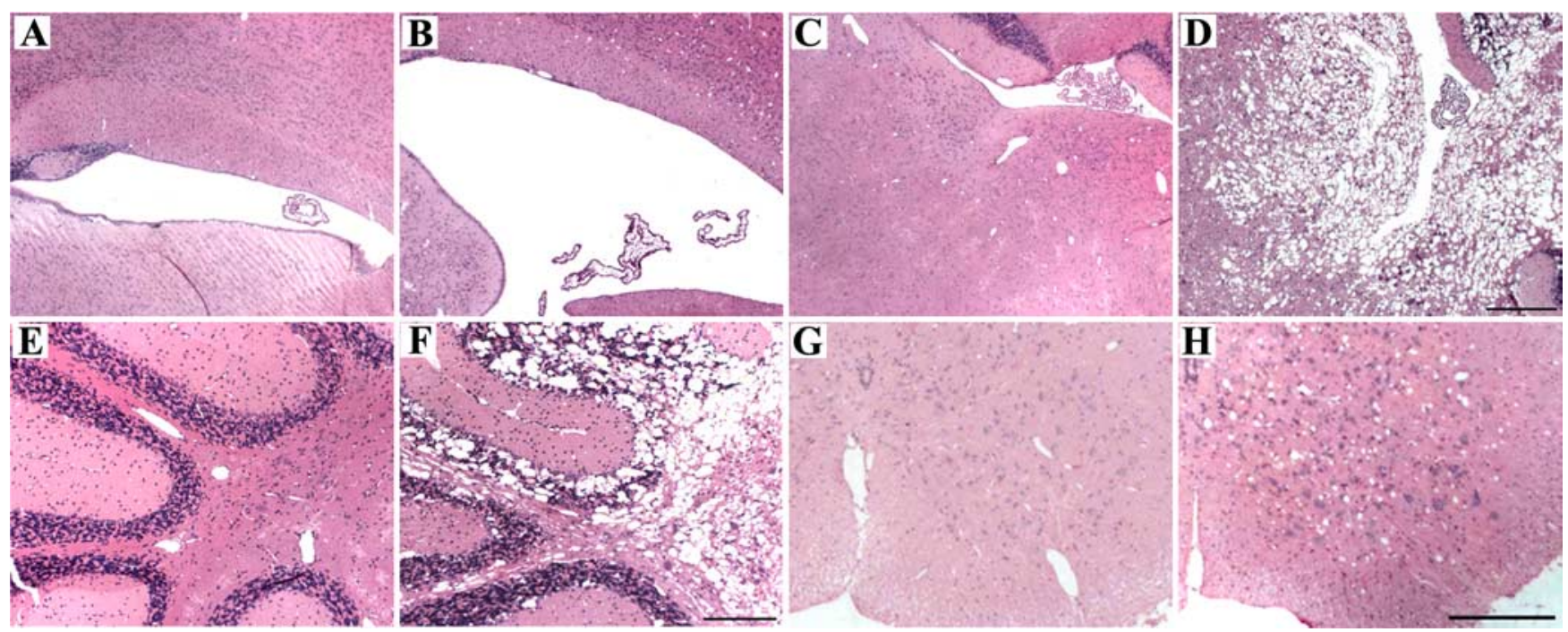

Figure 7. Vacuolation worsens with age in Aspan ${ }^{\text {nur7 }}$ mutants. At P70, the Aspan ${ }^{\text {nur7 }}$ mutants displayed a noticeable dilation of the lateral ventricles $(\boldsymbol{B})$ as well as increased vacuolation in the brainstem (dorsomedial pons, $\boldsymbol{D}$ ) and the cerebellum $(\boldsymbol{F})$ on $\mathrm{HE}$-stained paraffin brain sections. At this age, vacuoles were also found in the spinal cord gray matter area $(\boldsymbol{H})$, whereas the white matter looked normal. Corresponding control regions for $\boldsymbol{B}, \boldsymbol{D}, \boldsymbol{F}$, and $\boldsymbol{H}$ are shown in $\boldsymbol{A}, \boldsymbol{C}, \boldsymbol{E}$, and $\boldsymbol{G}$. Scale bars: $200 \mu \mathrm{m}(\boldsymbol{A}-\boldsymbol{D}, \boldsymbol{G}, \boldsymbol{H}), 100 \mu \mathrm{m}(\boldsymbol{E}, \boldsymbol{F})$.

A

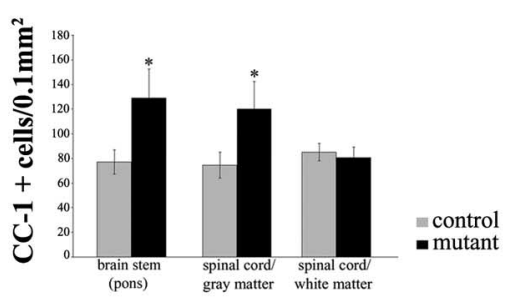

C

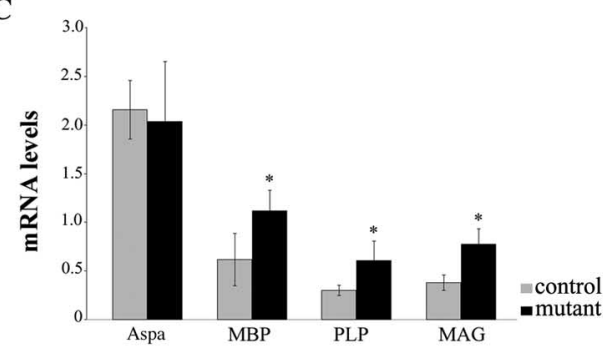

P70

$\mathbf{E}$

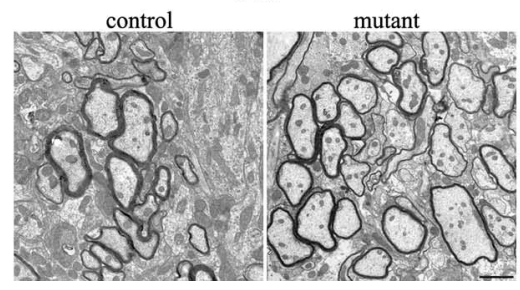

B

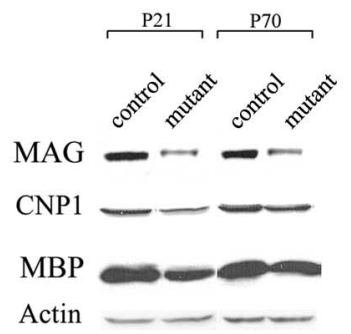

D

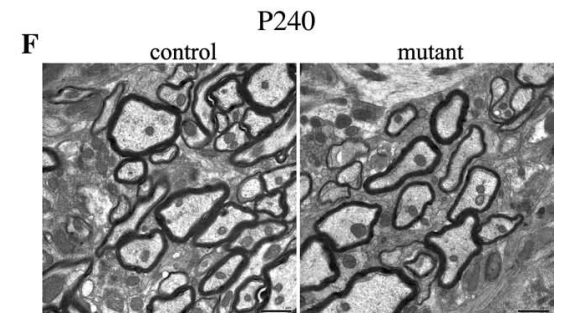

Figure 8. Increased oligodendrocyte numbers and higher myelin gene expression levels in $A s p a^{\text {nur7 }}$ mutants at P70.A,Aspa $a^{\text {nur } 7}$ mutants at $P 70$ showed increased oligodendrocyte numbers in the affected brainstem (medial pons) and spinal cord gray matter regions ( $\left.{ }^{*} p<0.05, n=4\right)$, whereas numbers matched control $\left(A s p a^{\text {nur } 7 /+}\right)$ values in the spinal cord white matter $(p>0.05$, $n=4)$. $B$, These mutants showed the same reduced levels of the MAG, CNP1, and MBP protein levels as P21 mutants compared with controls and $(\boldsymbol{C})$ they expressed normal Aspa $(p>0.05, n=4)$ and higher mRNA levels for MBP, PLP, and MAG $\left({ }^{*} p<0.05\right.$, $n=4$ ) compared with control mice. Error bars indicate SD of the mean. D, RT-PCR analysis for the S-MAG and L-MAG isoforms in P70 mutants and control mice showed that mutant oligodendrocytes expressed higher levels of the immature oligodendrocyte isoform L-MAG mRNA (154 bp product) compared with the mature cell isoform S-MAG (199 bp product), which predominates in control cells. $E$, EM analysis on the brainstem area (pons) showed that numerous axons were surrounded by a much thinner myelin sheath in the P70 mutant mice compared with controls. $F$, In P240 mutants, the same region showed patches with apparently normal myelinated axons under EM. Actin expression was used for data normalization in $\boldsymbol{B}$ and cyclophilin expression was used for data normalization in $\boldsymbol{D}$. Scale bars: $2 \mu \mathrm{m}(\boldsymbol{E}), 1 \mu \mathrm{m}(\boldsymbol{F})$.

control animals (Fig. 6C), indicating that their motor function is seriously impaired as a result of the spongy degeneration. This result also indicates that there are no major differences in the severity of the disease between $A s p a^{\text {nur } 7 / n u r 7}$ and $A s p a^{\text {nur } 7 / n u r} ; \mathrm{Cgt}^{+/-}$ mice.

\section{Progression of the disease pathology in} Aspa ${ }^{\text {nur }}$ mutants

The pathological defects progress with age in $A s p a^{n u r 7}$ mutants, which show a widening of the lateral ventricles at P70 (Fig. 7B) along with an expansion of vacuoles in the subcortical white matter (data not shown), the brainstem (dorsomedial pons) (Fig. $7 D$ ), and the cerebellum (Fig. $7 F$ ). Vacuolation, however, varies within different regions of the pons; the dorsal pons displayed more severe defects compared with other regions. Vacuoles were also detected in the spinal cord at this age, where the gray matter, but not the white matter, was affected (Fig. 7H). Despite the extensive vacuolation of the cerebellum and brainstem, the mutants show only slightly increased ataxia and tremor at P70 (supplemental Video 2, available at www.jneurosci.org as supplemental material).

Oligodendrocyte loss was not detected in Aspa $a^{\text {nur7 }}$ mutants at P70; instead increased oligodendroglial numbers were observed in the lesion sites of the brainstem (medial pons) and the spinal cord gray matter (Fig. 8A; supplemental Fig. $2 A-D$, available at www.jneurosci.org as supplemental material) compared with control mouse areas, whereas no changes were found in the normal-appearing white mater (Fig. $8 A$; supplemental Fig. $2 E, F$, 
available at www.jneurosci.org as supplemental material). Although Aspan mutants exhibited more pronounced myelin degeneration at P70 compared with P21, they did not show a further loss of myelin, because the protein levels of MAG, CNP1, and $\mathrm{MBP}$ appeared to be similarly reduced in both age groups (Fig. $8 \mathrm{~B}$ ). Moreover, Aspa $a^{\text {nur7/nur7 }}$ brains at P70 expressed normal Aspa and higher MBP, PLP, and MAG mRNA levels compared with control Aspa $a^{\text {nur7/+ }}$ brains of the same age (Fig. 8C), which may reflect an attempt by newly generated oligodendrocytes to synthesize myelin in the mutant animals. The above data raises the possibility that a remyelination effort might be occurring in Aspa $a^{\text {nur7/nur7 }}$ mice as they grow older, despite the worsening of their disease symptoms, with recruitment of new oligodendrocytes into the lesion sites. In support of this possibility, RT-PCR analysis for the developmentally regulated MAG isoforms showed that large MAG (L-MAG), the major isoform of immature oligodendrocytes, was expressed at higher levels in the mutant brain at P70 relative to small MAG (S-MAG), which predominates in the mature cells of control animals (Fig. 8D); the calculated S-MAG/L-MAG ratio was significantly lower in the mutants $(0.86 \pm 0.11)$ compared with controls ( $2.25 \pm 0.41, p<0.05, n=3)$. Additionally, thinly myelinated axons were found frequently in the affected brainstem area of $A s p a^{\text {nur } 7 / n u r 7}$ mice at P70 (Fig. $8 E$ ), further suggesting a remyelination effort. A myelin repair mechanism could also explain the patchy presence of axons with normal myelin thickness found in the brainstem of the older, P240 Aspa $a^{\text {nur7/nur7 }}$ mice (Fig. $8 F$ ), which nevertheless showed numerous completely demyelinated axons in the same region (data not shown).

The spongy degeneration worsens significantly over time in most lesion sites of $A s p a^{\text {nur7 }}$ mutants (Table 1). Nevertheless, the myelin rich regions of the corpus callosum, optic nerve and spinal cord white matter were found to be normal as late as P180 (Table 1). Conversely, the vacuolated regions of $A s p a^{\text {nur7 }}$ mutants showed a pronounced myelin degeneration, which worsens with age. Myelin degeneration might gradually impact the axonal integrity in the damaged areas, eventually causing the severe neurological phenotype displayed by the Aspan $a^{n u r}$ mutants at P300 (supplemental Video 3, available at www.jneurosci.org as supplemental material). We performed immunostaining for the axonal injury marker $\beta$ A4 amyloid precursor protein APP (Li et al., 1995, Bramlett et al., 1997) in the brain and the spinal cord of Aspa ${ }^{\text {nur7 }}$ mutants at P30 and P120. At P30, APP-positive axons were rare in the brain and the spinal cord of $A s p a^{\text {nur }}$ mutants. At P120, APP-positive axons were found much more frequently in the cerebellar white matter (Fig. 9B) compared with other CNS areas $\left(8.1 \times 10^{-6} \pm 1.37 \times 10^{-6}\right.$ axons $\left./ \mu \mathrm{m}^{2}, n=4\right)$. At P120, numerous vacuoles were present in this region (Fig. 9D), which also showed an $\sim 40 \%$ increased mean surface area at the coronal sectioning level compared with $A s p a^{\text {nur7/+ }}$ control mice (Fig. 9C). To assess quantitatively axonal loss in the cerebellum of $A s p a^{\text {nur }} 7$ mutants at P120, toluidine blue-stained semithin coronal sections from different cerebellar segments of two control (Fig. 9E) and two mutant mice (Fig. 9F) were examined. Axonal density counts were performed in the white matter area of the mutant $(n=12)$ and the control $(n=8)$ cerebellar segments; for com- parison purposes, the mutant values were normalized to the $40 \%$ increased white matter surface area found on HE-stained paraffin sections of the mutant cerebellum compared with the control. These data showed that the cerebellar white matter contained $\sim 30 \%$ fewer axons in Aspa $a^{\text {nur } 7 / n u r 7}$ mice (0.066 \pm 0.02 axons/ $\mu \mathrm{m}^{2}$ ) compared with Aspan $a^{\text {nur7/+ }}$ animals (0.096 \pm 0.01 axons/ $\left.\mu \mathrm{m}^{2}, p<0.05\right)$.

\section{Discussion}

ASPA is a 312 aa enzyme that specifically hydrolyzes NAA to acetate and aspartic acid in white matter (Kaul et al., 1991). More than 50 mutations have been identified in the human ASPA gene, most of them single base-pair changes in the coding region that usually result in loss of ASPA enzymatic activity because of a disruption in a critical functional domain of the protein. As such, $A s p a^{\text {nur7 }}$ is a novel nonsense mutation of the mouse Aspa gene that closely resembles the ASPA gene mutations that occur in CD patients. It generates a Q193X change, resulting in the premature termination of the protein at D192 and the subsequent truncation of its last 120 aa, a domain that includes the amino acid sequence motifs DCTV and VNEAAYY that are involved in Aspa's catalytic activity (Kaul et al., 1993; Zeng et al., 2002). Thus a truncated nonfunctional Aspa protein is predicted to be produced in Aspa $a^{\text {nur }}$ homozygotes. Nevertheless, no Aspa protein is detected in $A s p a^{\text {nur } 7 / n u r 7}$ mice, indicating that the truncated mutant protein is unstable.

The Aspa $a^{\text {nur } 7 / \text { nur } 7}$ mouse provides an important new model for the characterization of CD disease pathogenesis and the testing of therapeutic strategies. Interestingly, although the $A s p a^{n u r 7}$ mutation is effectively a null, which emerged on the C57BL/6J background, the mutants show a milder neurological phenotype and a longer life span compared with the Aspa-deficient knock-out mouse, which originated on the $129 \mathrm{~S}$ background and which displays considerable disease variability (Matalon et al., 2000). The differences in the disease phenotype displayed by the two mouse mutants might reflect genetic background differences. Alternatively, or additionally, these differences may originate because of the nature of the mutations. The Aspa knock-out locus is disrupted by the neo resistance gene under the transcriptional control of the PGK gene, which contains a strong transcriptional enhancer that has been shown to have the capacity to influence the expression of neighboring genes (Olson et al., 1996). Perhaps 
control

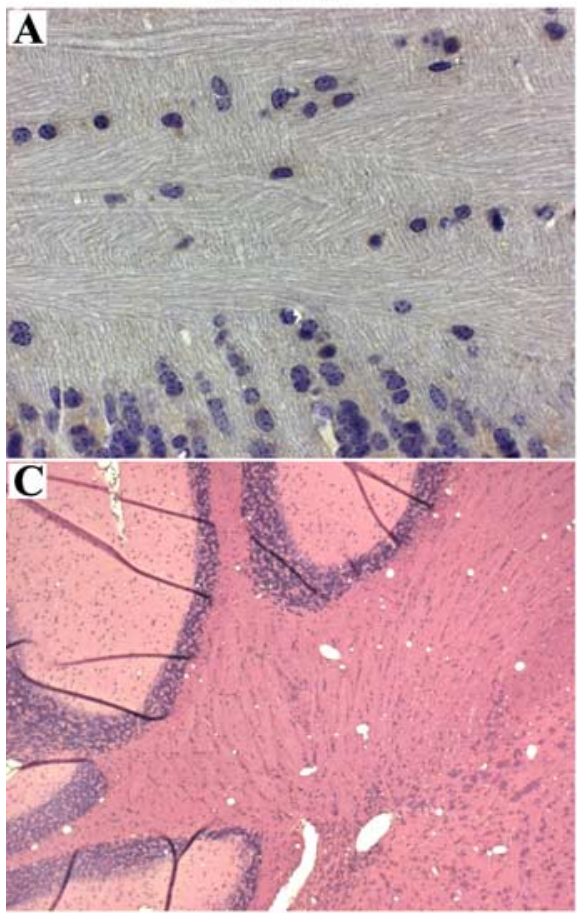

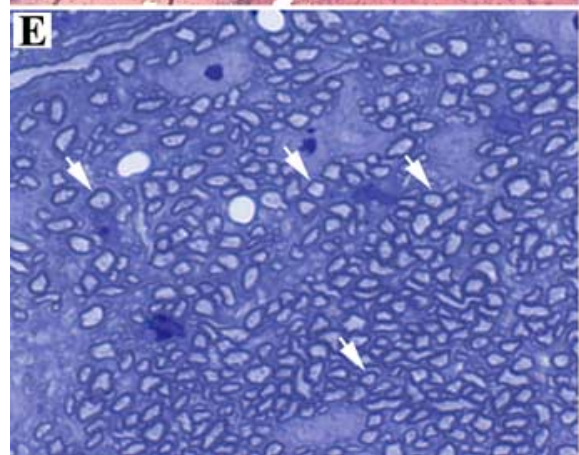

B

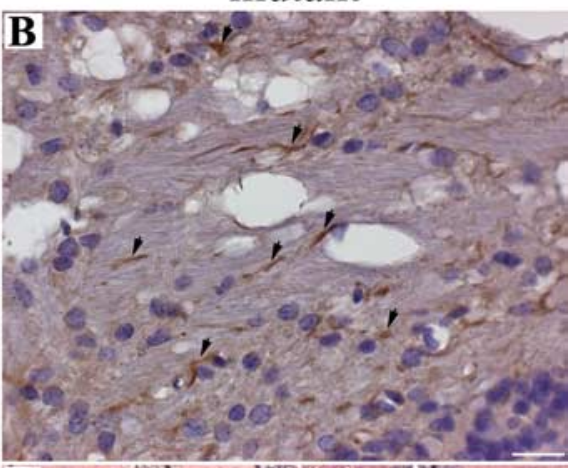

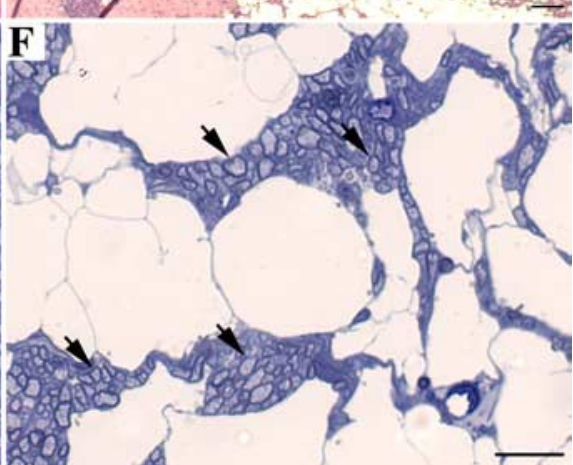

Figure 9. Significant axonal loss occurs in the cerebellum of $A s p a^{\text {nur7 }}$ mutants at P120. $\boldsymbol{A}, \boldsymbol{B}$, Immunostaining for the axonal injury marker APP identified positive axons in the cerebellar white matter of $A$ spa $a^{\text {nur7 }}$ homozygous (mutant) mice at P120 ( $\boldsymbol{B}$, arrows) and none in their heterozygous littermates (control, $\boldsymbol{A}$ ). $\boldsymbol{C}, \boldsymbol{D}$, An extensive vacuolation was also found on HE-stained paraffin sections of the mutant cerebellar white matter area $(\boldsymbol{D})$, which occupied an $\sim 40 \%$ increased mean surface area ( $65 \pm 11$ $\mathrm{mm}^{2}, n=3$ mice) compared with control mice (46 $\pm 2 \mathrm{~mm}^{2}, n=3$ mice) of the same age (C). $\boldsymbol{E}, \boldsymbol{F}$, Toluidine blue-stained coronal sections of cerebellar segments from P120 control $(\boldsymbol{E})$ and mutant mice $(\boldsymbol{F})$ used for axonal density counts in the cerebellar white matter. Examples of axons counted are pointed by arrows in $\boldsymbol{E}$ and $\boldsymbol{F}$. Scale bars: $20 \mu \mathrm{m}(\boldsymbol{A}, \boldsymbol{B}), 10 \mu \mathrm{m}(\boldsymbol{E}, \boldsymbol{F}), 100 \mu \mathrm{m}(\boldsymbol{C}, \boldsymbol{D})$.

3 in 1000. Moreover, multiple founders were used in our mapping studies, further decreasing the possibility of a mutation outside of the Aspa gene.

Aspa deficiency results in the formation of vacuoles in the $A s p a^{\text {nur }}$ mutant brain, which is characterized by the breakdown of the myelin sheath through lamellar splitting that takes place early in the majority of the affected CNS regions examined. Our data on the P14 Aspanur7 mutants showed that vacuolation initiates in the absence of significant oligodendrocyte loss, suggesting that the cell loss observed at P21 is secondary to the myelin sheath defects. Moreover, we found that the cerebellar lesions that develop in $A s p a^{\text {nur7/nur7 }}$ mice involve the early formation of vacuoles in the white matter region, as well as in the neuronal-rich Purkinje cell and granule cell layers without evidence of affecting the viability of these neurons. Interestingly, the Purkinje cell layer vacuoles, as well as a subset of the granule cell layer vacuoles, are not associated with myelin but seem to be formed by degenerating processes of an undetermined cell type, which raises the possibility that myelin sheath damage is not the exclusive source of CD pathology.

Currently, it is not clear how the deficient hydrolysis of neuronally derived NAA that characterizes CD results in myelin sheath defects and oligodendrocyte loss (Matalon et al., 1995). NAA-derived acetate has been shown to participate in the synthesis of the myelin lipids (D'Adamo and Yatsu 1966; D'Adamo et al., 1968; Chakraborty et al., 2001). In addition, a study by Madhavarao et al. (2005) has shown reduced acetate levels in the brain of the Aspa knock-out mouse, which may result in the impaired synthesis of myelin lipids found in these animals. In the same study, reduced cerebroside levels were detected in the brain of a human CD

the more severe phenotype of the knock-out mouse is caused by such a regional effect of the neo insertion on genes surrounding the Aspa locus, which is present in a relatively gene-rich area of chromosome 11. Similarly, the spontaneous Aspa-deficient tremor rat (Kitada et al., 2000) carries a deletion of the Aspa gene as part of a $>200 \mathrm{~kb}$ deletion that includes a number of neighboring genes, which likely explains the observation that both homozygous and heterozygous tremor rats display epileptic symptoms that do not correlate with spongiform degeneration in the CNS. Thus, the Aspa $a^{\text {nur }}$ mutant provides an authentic model for $\mathrm{CD}$ that should prove useful in uncovering critical information regarding the development and progression of this disease. Although the presence of another mutant gene located within the nur7 critical region of chromosome 11 that contributes to the mutant phenotype cannot be excluded, this is very unlikely; Kile et al. (2003) has estimated that the likelihood of ENU inducing two mutations on one chromosome of the C57BL/6J strain is only patient, thus supporting myelin lipid deficiency as underlying the pathogenesis of myelin degeneration in CD. We also show here that NFA-containing Galc cerebroside is decreased in the brain of Aspan $a^{\text {nur7/nur7 }}$ mice, as is PE. Our data are in agreement with the results of Ledeen et al., 2006 who used older (9 weeks old) Aspadeficient mice to detect reduced amounts $(\sim 65 \%)$ of cerebroside- 1 and a small decrease in PE. Nevertheless, the selective preservation of myelin rich regions in $A s p a^{n u r 7}$ mutants contradicts the hypothesis that Aspa's biosynthetic role in supplying acetate through NAA hydrolysis is critical for myelin maintenance. These mice show a spongy degeneration that mostly affects the cerebellum, the brainstem, and subcortical white matter, whereas other myelin rich areas such as the optic nerve, corpus callosum, and spinal cord white matter remain remarkably intact. Likewise, a regional variation of pathological defects occurs in human CD, which is mostly characterized by subcortical and cerebellar spongy degeneration (Adachi et al., 1973) that is reca- 
pitulated in the Aspa deficient rodent models, including the tremor rat (Kondo et al., 1991) and the Aspa knock-out mouse (Matalon et al., 2000). Thus, it is possible that the peculiar CNS pathology observed in CD patients might arise from the accumulation of an unidentified toxic metabolite specifically in the affected areas because of their inability to hydrolyze NAA.

Another CD feature that contradicts the myelin lipid deficiency hypothesis is the phenotypic differences present between Aspa $a^{\text {nur7/nur7 }}$ mice and Cgt mutant mice (Coetzee et al., 1996). In $\mathrm{Cgt}^{-1-}$ mice (Coetzee et al., 1996), loss of Cgt activity, the critical enzyme for cerebroside biosynthesis, results in disruption of paranodal junctions throughout CNS myelin without affecting oligodendrocyte survival (Marcus et al., 2000; Dupree et al., 1998, 1999), whereas in Aspanur7/nur7 mice, Aspa deficiency results in loss of oligodendrocytes and myelin sheath degeneration only in specific areas. Also in contrast to $C g t^{-/-}$mice, the Aspa $a^{\text {nur7/nur7 }}$ mice showed normal paranodal junctions (data not shown), indicating that vacuolation is not attributable to compromised axoglial contact in the paranodal region. Furthermore, in mice heterozygous for the Cgt mutation cerebrosides are synthesized at reduced levels compared with wild-type mice (Coetzee et al., 1996). Despite their reduced cerebroside levels, the $\mathrm{Cgt}^{+/-}$mice are normal and show no similarities to $A s p a^{\text {nur } 7}$ mutants.

To explore further the contribution of reduced cerebroside amounts in CD pathology, we used the $A s p a^{\text {nur7 }}$ mutants to generate $A s p a^{\text {nur7/nur7 }} ; \mathrm{Cgt}^{+/-}$mice, which carry a null $C g t$ allele. Cerebroside levels are below normal in $A s p a^{\text {nur } 7 / n u r} 7$ mice and as expected these lipids were further reduced in the Aspa $a^{\text {nur } 7 / n u r 7}$; $\mathrm{Cgt}^{+/-}$mice. The proposed role of reduced cerebroside synthesis in CD pathogenesis would predict a worsened disease in $A s p a^{\text {nur7/nur7 }} ; \mathrm{Cgt}^{+/-}$mice compared with Aspa $a^{\text {nur7/nur7 }}$ ones. Nevertheless, the double mutants showed a phenotype that closely resembles the single mutants. Thus, our data suggest that the reduced synthesis of cerebrosides detected in CD (Madhavarao et al., 2005) is not a major disease-contributing factor.

It has been reported that in human CD there is increased oligodendrocyte density in the demyelinated areas, which has been attributed to the condensation of the tissue (Adachi et al., 1973). In Aspa $a^{\text {nur } / \text { nur }}$ mice, oligodendrocyte loss occurs early, at $\mathrm{P} 21$, along with extensive vacuolation, followed by recruitment of new oligodendrocytes and upregulation of myelin gene expression levels at P70, which may be responsible for the appearance of normally myelinated axons in the affected brain areas of older mutants. This finding suggests that the increased numbers of oligodendrocytes found in the lesion sites of human CD patients might be evidence of an effort to remyelinate. Nevertheless, the human disease shows a progressive phenotype leading to mental retardation, blindness, motor function defects and early death (Adachi et al., 1973; Matalon et al., 1995). Our studies showed that significant axonal loss occurs in the cerebellum of older Aspa $a^{\text {nur }}$ mutants, correlating with the severe ataxia that develops at later disease stages. These data suggest that myelin degeneration in CD leads to axonal damage and loss, which might be the underlying cause of motor and sensory disabilities that patients develop in advanced-stage disease.

In summary, the Aspa-deficient mouse mutant $A s p a^{n u r} 7$ develops spongy degeneration throughout the CNS that strikingly resembles CD neuropathology in humans. This new authentic model for $\mathrm{CD}$, which is available upon request, should help to dissect the molecular pathways that are affected in CD as a result of Aspa deficiency. Moreover, this model should prove valuable in efforts to test therapeutic strategies.

\section{References}

Adachi M, Schneck L, Cara J, Volk BW (1973) Spongy degeneration of the central nervous system (van Bogaert and Bertrand type; Canavan's disease). A review. Hum Pathol 4:331-347.

Baslow MH, Suckow RF, Sapirstein V, Hungund BL (1999) Expression of aspartoacylase activity in cultured rat macroglial cells is limited to oligodendrocytes. J Mol Neurosci 13:47-53.

Benjamins JA, Miller SL, Morell P (1976) Metabolic relationships between myelin subfractions: entry of galactolipids and phospholipids. J Neurochem 27:565-570.

Bhakoo KK, Craig TJ, Styles P (2001) Developmental and regional distribution of aspartoacylase in rat brain tissue. J Neurochem 79:211-220.

Bhakoo KK, Craig T, Pearce D (2006) N-acetylaspartate metabolism in neural cells. Adv Exp Med Biol 576:27-47; discussion 361-363.

Blüml S (1999) In vivo quantitation of cerebral metabolite concentrations using natural abundance 13C MRS at 1.5 T. J Magn Reson 136:219-225.

Bramlett HM, Kraydieh S, Green EJ, Dietrich WD (1997) Temporal and regional patterns of axonal damage following traumatic brain injury: a beta-amyloid precursor protein immunocytochemical study in rats. J Neuropathol Exp Neurol 56:1132-1141.

Burri R, Steffen C, Herschkowitz N (1991) N-acetyl-L-aspartate is a major source of acetyl groups for lipid synthesis during rat brain development. Dev Neurosci 13:403-411.

Canavan MM (1931) Canavan, Schilder's encephalitis perioxalis diffusa. Neurology 15:299-308.

Chakraborty G, Mekala P, Yahya D, Wu G, Ledeen RW (2001) Intraneuronal $\mathrm{N}$-acetylaspartate supplies acetyl groups for myelin lipid synthesis: evidence for myelin-associated aspartoacylase. J Neurochem 78:736-745.

Coetzee T, Fujita N, Dupree J, Shi R, Blight A, Suzuki K, Suzuki K, Popko B (1996) Myelination in the absence of galactocerebroside and sulfatide: normal structure with abnormal function and regional instability. Cell 86:209-219.

D'Adamo AF Jr, Yatsu FM (1966) Acetate metabolism in the nervous system. N-acetyl-L-aspartic acid and the biosynthesis of brain lipids. J Neurochem 13:961-965.

D’Adamo AF Jr, Gidez LI, Yatsu FM (1968) Acetyl transport mechanisms. Involvement of $\mathrm{N}$-acetyl aspartic acid in de novo fatty acid biosynthesis in the developing rat brain. Exp Brain Res 5:267-273.

D'Adamo AF Jr, Smith JC, Woiler C (1973) The occurrence of $\mathrm{N}$-acetylaspartate amidohydrolase (aminoacylase II) in the developing rat. J Neurochem 20:1275-1278.

Dugas JC, Tai YC, Speed TP, Ngai J, Barres BA (2006) Functional genomic analysis of oligodendrocyte differentiation. J Neurosci 26:10967-10983.

Dupree JL, Coetzee T, Blight A, Suzuki K, Popko B (1998) Myelin galactolipids are essential for proper node of Ranvier formation in the CNS. J Neurosci 18:1642-1649.

Dupree JL, Girault JA, Popko B (1999) Axo-glial interactions regulate the localization of axonal paranodal proteins. J Cell Biol 147:1145-1152.

Folch J, Lees M, Sloane Stanley GH (1957) A simple method for the isolation and purification of total lipides from animal tissues. J Biol Chem 226:497-509.

Fujita N, Kemper A, Dupree J, Nakayasu H, Bartsch U, Schachner M, Maeda N, Suzuki K, Popko B (1998) The cytoplasmic domain of the large myelin-associated glycoprotein isoform is needed for proper CNS but not peripheral nervous system myelination. J Neurosci 18:1970-1978.

Hershfield JR, Madhavarao CN, Moffett JR, Benjamins JA, Garbern JY, Namboodiri A (2006) Aspartoacylase is a regulated nuclear-cytoplasmic enzyme. FASEB J 20:2139-2141.

Kaul R, Casanova J, Johnson AB, Tang P, Matalon R (1991) Purification, characterization, and localization of aspartoacylase from bovine brain. J Neurochem 56:129-135.

Kaul R, Gao GP, Balamurugan K, Matalon R (1993) Cloning of the human aspartoacylase cDNA and a common missense mutation in Canavan disease. Nat Genet 5:118-123.

Kile BT, Hentges KE, Clark AT, Nakamura H, Salinger AP, Liu B, Box N, Stockton DW, Johnson RL, Behringer RR, Bradley A, Justice MJ (2003) Functional genetic analysis of mouse chromosome 11. Nature 425:81-86.

Kirmani BF, Jacobowitz DM, Namboodiri MA (2003) Developmental increase of aspartoacylase in oligodendrocytes parallels CNS myelination. Brain Res Dev Brain Res 140:105-115.

Kitada K, Akimitsu T, Shigematsu Y, Kondo A, Maihara T, Yokoi N, Kuramoto T, Sasa M, Serikawa T (2000) Accumulation of N-acetyl-L- 
aspartate in the brain of the tremor rat, a mutant exhibiting absence-like seizure and spongiform degeneration in the central nervous system. J Neurochem 74:2512-2519.

Kondo A, Nagara H, Akazawa K, Tateishi J, Serikawa T, Yamada J (1991) CNS pathology in the neurological mutant rats zitter, tremor and zittertremor double mutant (spontaneously epileptic rat, SER). Exaggeration of clinical and neuropathological phenotypes in SER. Brain 114:979-999.

Le Belle JE, Harris NG, Williams SR, Bhakoo KK (2002) A comparison of cell and tissue extraction techniques using high-resolution 1H-NMR spectroscopy. NMR Biomed 15:37-44.

Ledeen RW, Wang J, Wu G, Lu ZH, Chakraborty G, Meyenhofer M, Tyring SK, Matalon R (2006) Physiological role of N-acetylaspartate: contribution to myelinogenesis. Adv Exp Med Biol 576:131-143; discussion 361-363.

Li GL, Farooque M, Holtz A, Olsson Y (1995) Changes of beta-amyloid precursor protein after compression trauma to the spinal cord: an experimental study in the rat using immunohistochemistry. J Neurotrauma 12:269-277.

Madhavarao CN, Moffett JR, Moore RA, Viola RE, Namboodiri MA, Jacobowitz DM (2004) Immunohistochemical localization of aspartoacylase in the rat central nervous system. J Comp Neurol 472:318-329.

Madhavarao CN, Arun P, Moffett JR, Szucs S, Surendran S, Matalon R, Garbern J, Hristova D, Johnson A, Jiang W, Namboodiri MA (2005) Defective $\mathrm{N}$-acetylaspartate catabolism reduces brain acetate levels and myelin lipid synthesis in Canavan's disease. Proc Natl Acad Sci USA 102:5221-5226.

Manly KF, Olson JM (1999) Overview of QTL mapping software and introduction to map manager QT. Mamm Genome 10:327-334.

Marcus J, Dupree JL, Popko B (2000) Effects of galactolipid elimination on oligodendrocyte development and myelination. Glia 30:319-328.

Matalon R, Michals K, Sebesta D, Deanching M, Gashkoff P, Casanova J (1988) Aspartoacylase deficiency and N-acetylaspartic aciduria in human patients with Canavan disease. Am J Med Genet 29:463-471.

Matalon R, Kaul R, Casanova J, Michals K, Johnson A, Rapin I, Gashkoff P, Deanching M (1989) SSIEM Award. Aspartoacylase deficiency: the en- zyme defect in Canavan disease. J Inherit Metab Dis 12 [Suppl 2]:329-331.

Matalon R, Michals K, Kaul R (1995) Canavan disease: from spongy degeneration to molecular analysis. J Pediatr 127:511-517.

Matalon R, Rady PL, Platt KA, Skinner HB, Quast MJ, Campbell GA, Matalon K, Ceci JD, Tyring SK, Nehls M, Surendran S, Wei J, Ezell EL, Szucs S (2000) Knock-out mouse for Canavan disease: a model for gene transfer to the central nervous system. J Gene Med 2:165-175.

Moffett JR, Ross B, Arun P, Madhavarao CN, Namboodiri AM (2007) N-Acetylaspartate in the CNS: from neurodiagnostics to neurobiology. Prog Neurobiol 81:89-131.

Namboodiri AM, Moffett JR, Arun P, Mathew R, Namboodiri S, Potti A, Hershfield J, Kirmani B, Jacobowitz DM, Madhavarao CN (2006) Defective myelin lipid synthesis as a pathogenic mechanism of Canavan disease. Adv Exp Med Biol 576:145-163; discussion 361-363.

Neale JH, Bzdega T, Wroblewska B (2000) N-Acetylaspartylglutamate: the most abundant peptide neurotransmitter in the mammalian central nervous system. J Neurochem 75:443-452.

Norton WT, Poduslo SE (1973) Myelination in rat brain: method of myelin isolation. J Neurochem 21:749-757.

Norton WT, Cammer W (1984) Isolation and characterization of myelin. In: Myelin (Morell P, ed), pp 147-196. New York: Plenum.

Olson EN, Arnold HH, Rigby PW, Wold BJ (1996) Know your neighbors: three phenotypes in null mutants of the myogenic bHLH gene MRF4. Cell 85:1-4.

Pouwels PJ, Frahm J (1997) Differential distribution of NAA and NAAG in human brain as determined by quantitative localized proton MRS. NMR Biomed 10:73-78.

van Bogaert L, Bertrand I (1949) Sur une idiotie familiale avec degerescence sponglieuse de neuraxe (note preliminaire). Acta Neurol 49:572-587.

Zeng BJ, Wang ZH, Ribeiro LA, Leone P, De Gasperi R, Kim SJ, Raghavan S, Ong E, Pastores GM, Kolodny EH (2002) Identification and characterization of novel mutations of the aspartoacylase gene in non-Jewish patients with Canavan disease. J Inherit Metab Dis 25:557-570. 